Deep Sea Research Part II: Topical Studies in Oceanography

March 2017, Volume 137, Pages 335-348

http://dx.doi.org/10.1016/i.dsr2.2016.06.008

http://archimer.ifremer.fr/doc/00342/45318/

(c) 2016 Elsevier Ltd. All rights reserved.

\title{
Copepod colonization of organic and inorganic substrata at a deep-sea hydrothermal vent site on the Mid-Atlantic Ridge
}

\author{
Plum Christoph ${ }^{1,2,{ }^{*}}$, Pradillon Florence ${ }^{1}$, Fujiwara Yoshihiro, Sarrazin Jozee ${ }^{1}$ \\ ${ }^{1}$ Institut Carnot Ifremer EDROME, Centre de Bretagne, REM/EEP, Laboratoire Environnement Profond, \\ France \\ 2 Japan Agency for Marine-Earth Science and Technology, JAMSTEC, France \\ * Corresponding author : Christoph Plum, email address : chplum@web.de
}

\begin{abstract}
:
The few existing studies on deep-sea hydrothermal vent copepods indicate low connectivity with surrounding environments and reveal high endemism among vents. However, the finding of nonendemic copepod species in association with engineer species at different reduced ecosystems poses questions about the dispersal of copepods and the colonization of hydrothermal vents as well as their ecological connectivity.

The objective of this study is to understand copepod colonization patterns at a hydrothermal vent site in response to environmental factors such as temperature and fluid flow as well as the presence of different types of substrata. To address this objective, an in situ experiment was deployed using both organic (woods, pig bones) and inorganic (slates) substrata along a gradient of hydrothermal activity at the Lucky Strike vent field (Eiffel Tower, Mid-Atlantic Ridge). The substrata were deployed in 2011 during the MoMARSAT cruise and were recovered after two years in 2013.

Overall, copepod density showed significant differences between substrata types, but was similar among different hydrothermal activity regimes. Highest densities were observed on woods at sites with moderate or low fluid input, whereas bones were the most densely colonized substrata at the 2 sites with higher hydrothermal influence. Although differences in copepod diversity were not significant, the observed trends revealed overall increasing diversity with decreasing temperature and fluid input. Slates showed highest diversity compared to the organic substrata. Temperature and fluid input had a significant influence on copepod community composition, resulting in higher similarity among stations with relatively high and low fluid inputs, respectively. While vent-specialists such as dirivultids and the tegastid Smacigastes micheli dominated substrata at high vent activity, the experiment demonstrated increasing abundance and dominance of non-vent taxa with decreasing temperature and fluid input. Effects of the substratum type on community composition were not significant, although at sites with moderate or low fluid input, woods exhibited distinctive communities with high densities and relative abundance of the taxon Nitocrella sp.. In conclusion, copepod colonization and species composition were mainly influenced by hydrothermal fluid input and temperature rather than the type of substratum. The outcome of this study provides fundamental knowledge to better understand copepod colonization at hydrothermal vents
\end{abstract}


Keywords: Chemosynthetic ecosystems, Ecological connectivity, Biodiversity and ecosystem functioning, Community composition, Colonization experiment, Hydrothermal activity

\section{Introduction}

Hydrothermal vents are widely distributed along mid-ocean ridges, in back arc systems and even on volcanic seamounts (Van Dover 2000, Clark and O'Shea 2001). These physically highly disturbed ecosystems typically emit high-temperature fluids which are enriched in reduced chemicals and potentially toxic heavy metals (Von Damm 1998). The fluid chemistry is generally correlated with temperature, where higher temperatures are associated with 


\section{ACCEPTED MANUSCRIPT}

greater concentrations of sulfide- and metal-rich but oxygen depleted fluids (Sarradin et al. 2009, Zielinski et al. 2011, Van Dover 2014). Although hydrothermal vent fields are ephemeral systems, their activity can often last from several years, to decades or even centuries (Humphris et al. 2002).

In the rather homogenous deep-sea environment, hydrothermal vents form islands of biological productivity mainly fueled by the production of chemoautotrophic microorganisms which use the energy from the oxidation of reduced elements such as hydrogen sulphide or methane present in the vent fluids (Bennett et al. 2011). These microorganisms occur either in free-living communities, or as symbionts in vent invertebrates such as bathymodiolid mussels and siboglinid tubeworms (Childress and Fisher 1992, Karl 1995, Dubelier et al. 2008, 2014). The symbiont hosting vent megafauna can serve as ecosystem engineers, providing living space for a variety of smaller macro- and meiofaunal organisms which also rely on chemoautotrophic symbionts or directly feed on free-living microorganisms and other organic material (Levesque et al. 2003, Govenar et al. 2005, Gollner et al. 2006, 2007, Limén et al. 2008, Pradillon et al. 2009, Degen et al. 2012). The distribution and composition of these biological assemblages can be strongly influenced by changes in physico-chemical conditions at hydrothermal vents, depending on species-specific physiological tolerance to fluid chemistry and nutritional requirements (Sarrazin et al. 2015). In addition, biological factors such as competition and predation have been described as important drivers for the zonation of organisms along these abiotic gradients (Mullineaux et al. 2003, Gollner et al. 2010a).

Single hydrothermal vent fields are often separated by tens to hundreds of kilometers along a spreading ridge and even more between different ridges or back arc systems (German et al. 1996). Despite their isolated character, nascent hydrothermal vents are often rapidly colonized by recruiting vent organisms (Shank et al. 1998, Tsurumi and Tunnicliffe 2001, Marcus et al. 2009, Gollner et al. 2013). Recently, the mechanisms behind species distribution and 


\section{ACCEPTED MANUSCRIPT}

colonization processes became of particular interest in face of an increasing impact of human activities in the deep-sea, such as fishing, pollution and mining (Van Dover 2014).

The colonization of hydrothermal vents depends on species dispersal rates, larval recruitment and immigration from surrounding environments but also on physical factors such as currents, spreading rates and the temporal stability of vent systems (Vrijenhoek 2010). In order to better understand species distribution, connectivity of populations and colonization processes, previous studies conducted colonization experiments deployed at various reduced ecosystems by using different types of artificial substrata (Van Dover et al. 1988, Mullineaux et al. 1998, 2003, 2012 Pradillon et al. 2005, 2009, Kelly et al. 2007, Kelly and Metaxas 2008, Gollner et al. 2015a). Most of these studies used inorganic material to assess the mechanisms behind species dispersal and colonization. However, the connectivity of hydrothermal vents can be ensured by a variety of other habitats with reducing conditions potentially serving as stepping stones, including organic substrata such as whale bones or sunken wood. These habitats have been shown to host chemosynthetic communities and are thought to be suitable to maintain the dispersal of vent organisms on local and global scales (Smith and Kukert 1989, Distel et al. 2000, Bienhold et al. 2013). Based on these assumptions, more recent investigations included organic substrata in colonization experiments to investigate their potential to support the distribution of vent-associated organisms (Gaudron et al. 2010, Böggemann et al. 2012, Bienhold et al. 2013, Cuvelier et al. 2014, Kalenitchenko et al. 2015, Szafranski et al. 2015, Zeppilli et al. 2015). The outcomes of these experiments suggest that the recruitment and settlement of vent organisms on the deployed substrata were interactively influenced by a variety of abiotic factors including the type of substratum, local physico-chemical conditions of microhabitats, the intensity of hydrothermal emission and the composition of natural background communities but also biological interactions such as predation and competition. While most of the previous studies were focused on macrofaunal organisms, information on the dispersal and colonization of meiofauna at hydrothermal vents is very limited, although 


\section{ACCEPTED MANUSCRIPT}

their ecological importance in marine ecosystems has been frequently acknowledged (Danovaro 2009, Lebreton et al. 2012, Giere 2013). Early investigations provided first insights into meiofaunal communities at hydrothermal vents (Dinet et al. 1988, Shirayama 1992), but only recently were they included in quantitative ecological studies (Tsurumi et al. 2003, Gollner et al. 2006, 2010 a, 2015 a, 2015 b, Zekely et al. 2006 a, b, Degen et al. 2012, Sarrazin et al. 2015). According to these studies, the meiofauna can make up to $50 \%$ of total local diversity at a hydrothermal vent site. However, vent meiofaunal communities often show low diversity and densities compared to the surrounding deep-sea sediments (Degen et al. 2012). Their composition and abundance can be correlated with the abiotic and biotic conditions of the local microhabitats (Ivanenko et al. 2011, Ivanenko et al. 2012, Sarrazin et al. 2015). To date, most of the investigated meiofaunal communities at hydrothermal vents are dominated by nematodes and copepods (Zekely et al. 2006a, Gollner et al. 2007, Degen et al. 2012, Sarrazin et al. 2015). Copepods are usually the second most abundant meiofauna taxon, but on basalts and sulfide chimneys found at hydrothermal vents they can be the most abundant and diverse meiofaunal taxon (Tsurumi et al. 2003, Gollner et al. 2007). Vent specific copepods often show low connectivity with the surrounding environment and high endemism (Zekely et al. 2006, Goller et al. 2010, Degen et al. 2012). The vent-endemic family Dirivultidae often dominate the copepod communities at vent systems (Ivanenko et al. 2006, Gollner et al. 2010b), but other copepod taxa known from non-vent habitats were also reported (Tsurumi et al. 2003, Cuvelier et al. 2014, Sarrazin et al. 2015). Currently, there are more than 80 species described from hydrothermal vents, belonging to five different orders, namely the Calanoida, Cyclopoida, Harpacticoida, Poecilostomatoida and Siphonostomatoida, of which the latter contains more than 50 species (Heptner and Ivanenko 2002, Ivanenko and Defaye 2004, Ivanenko et al. 2011). Previous findings of non-endemic copepod species in association with engineer species at different reduced ecosystems pose questions about the mechanisms for the colonization of hydrothermal vents and their connectivity on larger scales 


\section{ACCEPTED MANUSCRIPT}

(Heptner and Ivanenko 2002, Ivanenko et al. 2012, Sarrazin et al. 2015, Plum et al. 2015).

Recently, pilot experimental studies using organic and inorganic substrata deployed at the Lucky Strike vent field have included meiofaunal organisms, mainly nematodes and copepods, for the first time in order to assess their colonization patterns at a deep-sea hydrothermal vent site (Cuvelier et al. 2014, Zeppilli et al. 2015). They showed significant differences in community composition between different substrata, however, the influence of the local environmental conditions and hydrothermal activity turned out to have a stronger influence.

Despite the progress in the investigation of vent meiofauna, recruitment and colonization patterns of these small sized organisms at hydrothermal vents, in particular the copepods, remain poorly understood. Therefore, the objective of this study was to investigate copepod colonization processes at a deep-sea hydrothermal vent site in response to environmental factors such as temperature, fluid flow and the presence of different substrata. This was experimentally assessed by using three different types of substrata (wood, bone and slate) that were deployed along a physico-chemical gradient in the vicinity of the Eiffel Tower edifice at the Lucky Strike vent field located on the Mid-Atlantic Ridge (MAR), within the frame of an integrative study on colonization processes at hydrothermal vents. The following questions were addressed:

1) Does the copepod density, diversity and community composition differ between substratum types?

2) How are the copepod communities influenced by the environmental conditions such as changes in temperature and fluid input?

3) Are there indicator species representing specific microhabitats? 


\section{Material and Methods}

\section{Study area}

The Lucky Strike (LS) vent field is located on the MAR, south of the Azores. This vent field is characterized by multiple edifices situated around a central lava lake with a diameter of 200 m (Fig. 1). The deployment experiment analyzed here was placed in the vicinity of the Eiffel Tower edifice, an $11 \mathrm{~m}$ high and well-defined active hydrothermal vent south-east of the lava lake. This site has been intensively investigated during several cruises within the last decades (Van Dover et al. 1996, Desbruyères et al. 2001, De Busserolles et al. 2009, Cuvelier et al. 2009, 2011, 2012, Sarrazin et al. 2009, 2014, 2015) and is the focus of a series of colonization experiments, started in 2006 (Cuvelier et al. 2014, Zeppilli et al. 2015).

\section{Experimental setup}

This study concerns the deployment of three different types of substrata, including slates (A), woods (B) and pig bones (C), during the MoMARSAT 2011 cruise. The types of substrata were chosen to mimic organic falls (wood, bone) as well as the bare basalt (slate) found at the LS vent field. Prior to the deployment, the surface area was evaluated for each of them with the aid of a 3D imaging technique using a calibration grid and images taken at different angles (coll. Dr. M. Aron, ISEN engineering school). The substrata were deployed at five different sites (S1-5) along a gradient of hydrothermal activity on and around the Eiffel Tower edifice, resulting in the total number of 15 ( 5 x 3) substrata (Fig. 1). Sites 1-3 were situated on and at the base of the edifice. These sites were chosen in correspondence to those reported in previous studies (Cuvelier et al. 2014, Zeppilli et al. 2015). Site 1 was the least active area in the close vicinity of the edifice (low fluid input). Site 2 was located towards the north-west of the Eiffel Tower edifice within the most active area among the selected sites (high fluid input). This site showed the denser assemblages of Bathymodiolus azoricus. Substrata at site 3 


\section{ACCEPTED MANUSCRIPT}

were placed on a crack with diffuse fluid flow (intermediate fluid input) characterized by the presence of Bathymodiolus azoricus and microbial mats. Site 4 was located $25 \mathrm{~m}$ south of the center, between the Eiffel Tower and Montsegur edifice (Fig. 1) and was chosen as an external site with limited hydrothermal input, corresponding to site 4 reported in Zeppilli et al. (2015). An additional set of substrata was placed at site 5 which was situated in the lava lake (Fig. 1), representing an inactive area with the lowest influence of hydrothermal fluids. One of three substrata deployed at the different sites was equipped with an autonomous temperature probe (NKE ST 6000), which recorded the local temperature in 15 minutes intervals during the entire deployment period. Temporal series of environmental data collected since 2010 with the multidisciplinary observatory EMSO-Açores (Colaço et al. 2011) at LS provided additional environmental information.

\section{Environmental conditions}

The sites were characterized by different temperatures. We calculated the average temperature for each site based on the data obtained from the probes deployed with the substrata during several cruises from 2011 to 2015. In addition, we evaluated minimum and maximum temperatures for each site (Table 1). Previous studies have demonstrated that temperature at the LS vent field is a good proxy of the chemical characteristics of the vent fluids (Sarradin et al. 2009, Cuvelier et al. 2014, Sarrazin et al. 2015). For example, at Eiffel Tower, it has been shown that temperature correlates positively with total dissolved sulphide and iron concentrations (De Busserolles et al. 2009).

In our dataset, the highest average temperature $\left(7.3^{\circ} \mathrm{C}\right)$ was observed at site 2 representing the site with highest fluid inputs. Intermediate temperature $\left(5.5^{\circ} \mathrm{C}\right)$ and fluid inputs were detected at site 3 while site 1 showed slightly lower temperatures $\left(4.8^{\circ} \mathrm{C}\right)$ and fluid inputs. The average 


\section{ACCEPTED MANUSCRIPT}

temperature at the external site 4 was $4.7^{\circ} \mathrm{C}$ while site 5 showed the lowest average temperature $\left(4 \cdot 5^{\circ} \mathrm{C}\right)$. For maximum and minimum temperatures see Table 1.

A gross estimation of fluid input can be obtained using the formula proposed by Sarradin et al. (2009): $\%=0.314 * \mathrm{~T}-1.38$, calculated with the Eiffel Tower end-member temperature of $324{ }^{\circ} \mathrm{C}$ reported in Charlou et al. (2000) and the ambient temperature of $4.4{ }^{\circ} \mathrm{C}$. Using this calculation, fluid inputs varied from $0.9 \%$ of hydrothermal fluids at the most active site to $0.05 \%$ at the most distant site 5 (Table 1). The fluid inputs for each site calculated by this formula are given in Table 1. Because of the described inter-correlation of vent abiotic conditions, we tested for correlations between the variables to determine the best explanatory ones. We finally used maximum temperature and fluid input to test the effect of environmental factors on the variation in taxonomic composition (see statistical analyses).

\section{Sample treatment}

The different substrata were recovered in 2013 during both the BIOBAZ and MoMARSAT cruises. All substrata were recovered, except for the bone substratum deployed at site 5 which has disappeared. The recovered substrata were placed in individual isotherm sampling boxes to avoid cross contamination between the substrata and loss of organisms.

On board, the recovered substrata as well as the sampling boxes were carefully rinsed over sieves with 1000-, 300-, and $20 \mu \mathrm{m}$ mesh sizes, respectively. The samples were preserved in seawater-buffered formalin (10\%) with a final concentration of $4 \%$. In the lab, samples were rinsed again and transferred to $200 \mathrm{ml}$ plastic beakers. Due to the partly very high abundance of organisms, we decided to subsample part of the samples obtained from the substrata washings. Therefore, three subsamples of $5 \mathrm{ml}$ each were taken from the original sample volume. All copepods from each subsample were then collected and counted. Total 


\section{ACCEPTED MANUSCRIPT}

abundance was calculated by using the average copepod individual number per subsample and extrapolated to the original sample volume. All copepod individuals collected from the subsamples were then transferred to glycerin and mounted on glass slides for species identification using a Leica microscope with phase contrast. A total of 26,021 specimens were identified to species level.

\section{Statistical analyses}

Due to the different surface areas of the substrata, copepod abundance data were standardized to $10 \mathrm{~cm}^{2}$ surface area. We then calculated total copepod densities (including juveniles) and relative copepod abundance based on the number of adult individuals for each sample. The relative abundance of all species with $>5 \%$ of the total abundance is shown in a bar plot to display differences in community composition. Species diversity was assessed by calculating the expected number of species (ES) for a random sample size of 100 individuals (ES [100]). In contrast to other diversity indices such as Shannon-Wiener (H'loge), the ES does not refer to all species $(\mathrm{S})$ and individuals $(\mathrm{N})$ of the species-abundance data, but rather interpolates the species numbers expected in a sample of $\mathrm{n}$ individuals (Hulbert 1971). This allowed us to account for differences in the surface area of the deployed substrata and the sorted sample volume, enabling a direct comparison of copepod diversity between the different substrata and sampling sites. We additionally performed one-way ANOVAs on overall copepod density and diversity to test for significant differences between sites (S1-5) and substrata types (wood, slate, bone), respectively. Therefore, we considered either the sites (for differences between substrata) or the substrata types (for differences between sites) as replicates. Significant differences between groups were detected by Tukey's honest significant differences test (HSD, set at $\mathrm{p}<0.05$ ). To detect significant intra-sites differences between substrata and differences among replicate of the same substratum type between sites, we additionally performed the non-parametric Kruskal-Wallis-test. 
The copepod abundance data were Hellinger-transformed prior to the multivariate analyses (Legendre and Gallagher 2001). This transformation ensures that differences in abundance contribute to the dis/similarity between samples without giving to much weight to the very common or rare species (Legendre and Gallagher 2001). Analysis of similarity (ANOSIM) was used to evaluate significant differences in community composition between the deployed substrata and sites. Additionally, we performed similarity percentage (SIMPER) analyses to test for similarities between copepod communities and assess the percentage contribution of single copepod species to the similarities/dissimilarities between sites and substrata. A principal coordinate analyses (PCoA) was conducted to display (dis)similarities between samples. In order to assess and visualize species contribution to the variation in similarity among samples, we created a biplot of species and samples by correlating the original species vectors and the site scores along the most significant PCoA ordination axes. The PCoA was based on the Bray-Curtis similarity calculated from Hellinger-transformed abundance data. These analyses were conducted in the PRIMER v6 package (Clarke and Gorley 2006).

In order to evaluate the influence of environmental conditions on the variance in community composition, we additionally conducted a canonical RDA based on the Hellingertransformed abundance data. Forward selection was carried out and the adjusted R2 was selected as the criterion to enable fitting of the best explanatory environmental variables in the model. Indicator species analysis was conducted to identify the copepod taxa that were significantly associated with particular environmental conditions (De Cáceres and Legendre 2009, Legendre and Legendre 2012). The analyses were carried out using the vegan (Oksanen et al. 2012) and indicspecies (De Cáceres and Jansen 2011) packages in the R environment ( $R$ Development Core Team 2012). 


\section{Results}

\section{Copepod density and diversity}

Total copepod density was highly variable between substratum and sites. Consequently, total copepod density per site (including copepodites) showed no significant differences between individual sites (one-way ANOVA, $\mathrm{F}_{4,9}=0.248, \mathrm{p}=0.903$ ).

However, when testing for the overall effect of substratum types by combining all sites, copepod densities were significantly higher on wood panels compared to bones and slates, (one-way ANOVA, $\mathrm{F}_{2,11}=4.777, \mathrm{p}=0.032$ ). The wood panels revealed densities of up to 294.3 ind. $10 \mathrm{~cm}^{-2}$, while the slate panels showed the lowest densities across all sites with values ranging from 3.1 to 10.2 ind. $10 \mathrm{~cm}^{-2}$ (Table 2). In contrast to the overall effect of substratum types, differences were not significant, according to non-parametric tests, when comparing the individual substratum types between sites as well as different substratum types within individual sites.

However, trends in copepod density across sites and substrata can be observed (Fig. 2). Total copepod density per site tend to increase with decreasing fluid input among the active sites 2 , 3 and 1 but slightly decreased again at the inactive sites 4 and 5, mainly reflecting the density pattern on the wood substrata. Densities on bones gradually decreased from high vent activity (40.4 ind. $\left.10 \mathrm{~cm}^{-2}\right)$ to the external site $4\left(1.4\right.$ ind. $\left.10 \mathrm{~cm}^{-2}\right)$, while densities on slates were highest at intermediate activity, showing a decrease with further decreasing vent activity (Fig. 2). This resulted in different patterns within individual sites. At sites 2 and 3, bones exhibited highest densities followed by woods and slates (Fig. 2, Table 2). Wood panels revealed highest densities with decreasing hydrothermal activity (sites 1, 4 and 5). At site 1, the highest density was found on wood followed by the bone and the slate. At the external site 4 , bones 


\section{ACCEPTED MANUSCRIPT}

showed lowest densities compared to the other substrata. The individual densities of adults, copepodites and nauplii revealed similar patterns (Table 3) although the relative abundance of the individual developmental stages showed high variability across all sites (Fig. 2b).

The absolute species richness per site, i.e. species number from three substrata at one site, increased from 15 species at site 2 with high fluid input to 35 species at the inactive site 5 , resulting in a gradual increase in copepod diversity with decreasing temperature and fluid input (Table 3). Copepod species richness was highest on the slates $(S=37)$ followed by woods $(\mathrm{S}=26)$ and bones $(\mathrm{S}=18)$ when comparing the absolute species richness of individual substrata (Table 3). However, copepod diversity of individual substrata showed relatively high variability (Table 2). Amongst the different sites, species richness ranged from 8 to 14 among bones, from 7 to 16 on wood panels, and from 12 to 31 on slate panels. Across all sites, expected species richness (ES) was highest on slates, while wood panels exhibited lowest ES except for site 3.

Although the observed results revealed trends in copepod diversity, there were no significant differences in the diversity measures between the substratum types and sites, respectively (Table 2).

\section{Copepod community composition}

The adult copepods were assigned to 45 species, belonging to 15 families and 5 different orders among a total of 26,021 identified individuals (Table 3). Only 11 of the 45 species were assigned to already known species. The taxa Ambilimbus sp. and Kelleridae n. gen. n. sp., were identified as a new species and new genus respectively. The most species rich families were the Ameirida with 9 species, followed by the Ectinosomatidae with 7 species and the Miraciidae with 4 species. In total, 18 species with a relative abundance of $>5 \%$ dominated the communities on the deployed substrata. The most dominant species, in terms of their relative contribution to the overall abundance across all sites, were Nitocrella sp. (45\%), 


\section{ACCEPTED MANUSCRIPT}

Smacigastes micheli (18\%), Haifamera sp. (7\%), Tisbe sp. (6\%) and Xylora bathyalis (5\%).

Four species were restricted to the active sites, while 16 species were exclusively found at inactive sites 4 and 5. The only species that appeared in all samples was Miraciidae sp. 2. However, the relative abundance among individual substrata varied along the gradient of fluid input (Fig. 3).

At higher vent emission (site 2), six species revealed relative abundance of more than $5 \%$ across the different substrata. The dirivultid Aphotopontius atlanteus was the most dominant species on the slate panels (33\%) followed by S. micheli (30\%) and Tisbe sp. (22\%), while the cyclopoid Hepterina confusa contributed only $8 \%$ to the community. The species Miraciidae sp. 2 contributed roughly $43 \%$ to the community on the wood substratum followed by Tisbe sp. (>25\%) and A. atlanteus ( $>24 \%)$. The tegastid species S. micheli clearly dominated the community on the bone substratum with $75 \%$ of the relative abundance. The latter was also highly dominant in the communities of all substrata at intermediate vent emission (site 3), contributing roughly $69-79 \%$ to the relative abundance while Tisbe sp. contributed less than $10 \%$.

Species composition at low vent emission (site 1) was more heterogeneous compared to sites with higher hydrothermal activity. Across the three substrata at site 1 , seven species individually contributed more than $10 \%$ to the relative abundance, with Tisbe sp. being dominant on slate (>38\%), Nitocrella sp. on wood (>42\%) and X. bathyalis on bone (>32 \%) substrata.

The substrata at the external site 4 showed remarkable differences in species composition. While the slate panels harboured a rather heterogeneous community consisting of six species 


\section{ACCEPTED MANUSCRIPT}

with relative abundance varying between $\sim 5 \%$ and $\sim 23 \%$ and a total of $\sim 15 \%$ of "rare" species (Fig. 3 'others'), the wood and bone substrata were highly dominated by Nitocrella sp. ( $\sim 89 \%)$ and Ectinosomatidae sp. $1(\sim 72 \%)$, respectively. The same pattern was observed at the inactive site 5, showing an even higher contribution of "rare" species to the community found on slate $(\sim 42 \%)$ and high dominance of Nitocrella sp. on the wood substratum $(\sim 84$ $\%)$. The bone substratum was not recovered at site 5 .

The ANOSIM test showed significant differences in community composition between sites across all substratum groups $(\mathrm{p}<0.05, \mathrm{R}=0.573)$. In turn, there were no significant differences between the individual substratum types across sites $(\mathrm{p}=0.9, \mathrm{R}=0)$. However, similarity percentage analyses (SIMPER), revealed relatively high similarities between the different substrata within individual sites at high $(\sim 47 \%)$, intermediate $(\sim 70 \%)$, and low $(\sim$ $49 \%$ ) vent emission. The species $S$. micheli and Tisbe sp. explained most of the similarities between substrata within individual active sites with a cumulative contribution of $\sim 36$ to $\sim 74$ $\%$ to the average similarities, while a considerable contribution of the dirivultid A. atlanteus to the similarity between substrata was restricted to site $2(\sim 18 \%)$. With a contribution of $\sim 39 \%$ at site 4 and $\sim 62 \%$ at site 5 , the taxon Nitocrella sp. was mainly responsible for similarities between substrata within the external sites. However, the similarity between substrata within the individual sites was very low with $\sim 27 \%$ at site 4 and $\sim 19 \%$ at site 5 . Significant dissimilarities (SIMPER, $\sim 65$ to $\sim 81 \%$; SIMPROF, $\mathrm{p}=0.01$ ) were detected between the active sites (1-3) and the inactive sites (4 and 5).

Corresponding to the outcome of the ANOSIM and SIMPER analyses, the PCoA ordination plot (Fig. 4) grouped the samples according to the locality rather than the type of substratum. In particular, the substrata from sites with high to low vent emission (sites 1-3) were grouped on the one hand and samples from the external site 4 with the inactive site 5 on the other, indicating high dissimilarities between active and inactive sites, with the exception of wood 


\section{ACCEPTED MANUSCRIPT}

from site 1 (intermediate emission) being more similar to sites 4 and 5. The PCoA axis 1 (37.5 $\%)$ and $2(18.5 \%)$ combined explained $56 \%$ of the total variation in similarity between the samples. Similarities among the active sites can be assigned to the densities and relative abundance of S. micheli, A. atlanteus, Tisbe sp. and X. bathyalis. While the species S. micheli and $A$. atlanteus mainly contributed to the similarity between site 2 and $3, X$. bathyalis and Tisbe sp. were responsible for the similarity of site 1 with sites 2 and 3 . Taxa such as $B$. azorica, Ectinosomatidae sp. 1 and Nitocrella sp. in turn triggered the separation of the inactive sites (Fig. 4). High densities and dominance of Nitocrella sp. on B4 and B5 significantly contributed to the similarity of these samples. High similarities between wood of site 1 (B1) and slates of the inactive sites 4 and 5 (A4, A5) were triggered by the combination of Haifamera sp., and Nitocrella sp. as well as Ameira longipes. Although the total density of Ectinosomatidae sp. 1 was relatively low, it contributed more than $80 \%$ to the total relative abundance on the bone of site $4(\mathrm{C} 4)$ and therefore to the distinctiveness of the inactive sites.

\section{Copepod distribution and environmental conditions}

The outcome of the RDA analyses revealed that maximum temperature and fluid input significantly influenced the variance in copepod distribution (temp. $\max , \mathrm{p}=0.02$; fluid input, $\mathrm{p}=0.04)$ while the type of substratum had no significant effect. The first component of the RDA on the density data accounts for $26.03 \%$ of the variance in copepod distribution across the different sites and substrata (Fig. 5) while the second component represents only $7.48 \%$.

The RDA plot (Fig. 5) shows that the copepod assemblages found on the deployed substrata can be separated into two different communities along a gradient of maximum temperatures and fluid input: 1) the active sites (sites 1-3) which were mainly colonized by S. micheli, A. atlanteus, X. bathyalis and Tisbe sp. and 2) the external and inactive sites (sites 4 and 5) that 


\section{ACCEPTED MANUSCRIPT}

were preferentially colonized by Nitocrella sp., Ectinosomatidae sp. 1, B. azorica, Ameiridae sp. 4 and to a high percentage of less common species (up to $42 \%$ ).

\section{Indicator species}

The indicator species analysis was conducted in order to identify copepod species that can be significantly assigned to the different environmental conditions. Only 5 of the 46 identified species were characteristic for the two major habitats (active/inactive) determined in the investigated area. In correspondence with the RDA plot, the indicator species analysis demonstrated that the active sites were significantly represented by the species A. atlanteus ( $\mathrm{p}$ $=0.001)$, S. micheli $(\mathrm{p}=0.002)$ and $X$. bathyalis $(\mathrm{p}=0.028)$ while the inactive sites were represented by Ameiridae sp. 4 and B. azorica (both $\mathrm{p}=0.012$ ).

\section{Discussion}

\section{Overall composition}

In total, 45 copepod species belonging to 5 orders, 15 families and 20 genera were found in our substratum experiment. We were unable to assign the majority of the morphotypes to known species, which suggests that many of the taxa are probably new to science. Among them, one new species in the Erebonasteridae family (Ambilimbus sp. nov.) and one new genus (Kelleridae n. gen. n. sp., pers. comm. V. Ivanenko) were identified based on their morphological characters. The genus Ambilimbus was erected by Ivanenko et al. (2005) as a replacement for the genus Amphicrossus (Huys 1991). Members of this genus have been previously described from hydrothermal vents and other chemosynthetic ecosystems (Humes and Huys 1992, Martínez-Arbizu 1999, Ivanenko et al. 2005). The description of Ambilimbus arcuscelestis (Ivanenko et al. 2005) was the first record of erebonasterids on the Mid-Atlantic 


\section{ACCEPTED MANUSCRIPT}

Ridge (Rainbow vent field). With the identification of Ambilimbus sp. nov. and $A$. arcuscelestis, both found in the frame of our experiment, this genus is described for the first time from the LS vent field. The copepod belonging to a new genus within the family Kelleridae was observed in high abundance on the wood panel at site 5, representing the first record of this family near a hydrothermal vent. Additional taxonomic work is needed for the 33 unidentified taxa.

Across all sites, the deployed substrata harboured a very heterogeneous community including not only vent specific species but also uncommon copepod taxa that have not been described from hydrothermal vent sites. Interestingly, many of the observed species possessed one or two strong claw-like setae on the inner ramus of the first pair of swimming legs. This morphological character is often observed in epibenthic or shallow-water epiphytic species associated with hard substrata (Boxshall and Halsey 2004). In addition, species with this character have already been reported from different reduced deep-sea ecosystems in association with organic substrata and large engineer species (Hicks 1988, Gollner et al. 2006, 2007, 2008, Ivanenko et al. 2012, Cuvelier et al. 2014, Sarrazin et al. 2015, Plum et al. 2015). Consequently, copepod taxa possessing this feature, such as Smacigastes micheli, Tisbe sp., Archesola typhlops, Xylora bathyalis and Bathylaophonte azorica can be considered as typical epibenthic copepods associated with hard substrata. Sedimentary forms, which are rarely reported from hydrothermal vents, were also collected. These species, of which the majority belongs to the Ectinosomatidae, Ameridae and Miraciidae families, were mainly found in sedimentary environments of site 4 but also at site 5 which was characterized by bare basalt.

The relationships between the distribution of copepod taxa and environmental conditions at hydrothermal vents were rarely assessed (Tsurumi et al. 2001, Gollner et al. 2010a, Cuvelier 


\section{ACCEPTED MANUSCRIPT}

et al. 2014, Sarrazin et al. 2015). The outcome of the PCoA and the RDA suggests, that the sampling sites and deployed substrata can be separated into active (sites 1,2 and 3) and inactive (sites 4 and 5) habitats, characterized by specific environmental conditions. The community composition on the substrata changed gradually from active to inactive habitats along the gradient of temperature and fluid input, with an increasing heterogeneity as well as an increasing appearance of rare and exclusive species with decreasing fluid input. Based on their abundance and distribution patterns, the species A. atlanteus, S. micheli and X. bathyalis were identified as indicator species for the active habitats, while B. azorica and Ameiridae sp. 4 represented the inactive habitats. The concept of using indicator species that reflect differences in environmental conditions to identify distinctive vent habitats has been used previously (Sarrazin et al 2015). Their links with the environmental conditions at the LS vent field as well as their habitat preferences are discussed below.

The species Xylora bathyalis was almost entirely restricted to the active sites except for A5 where it occurred in very low abundance. At the active sites, it was mainly found on bones but also in relative high numbers on wood at site 1. Xylora bathyalis has been frequently found in reduced ecosystems such as wood falls off New Zealand (Humes 1973), at hydrothermal vents of the EPR (Gollner et al. 2006, 2010a), in association with large engineer species such as bathymodiolid mussels and siboglinid tubeworms at a natural oil seep in the Gulf of Mexico (Plum et al. 2015) as well as in Bathymodiolus azoricus mussel assemblages (Sarrazin et al. 2015) and in a previous colonization experiment on the LS vent field (Cuvelier et al. 2014). Based on these findings, it can be considered as an epibenthic specialist associated with hard substrata in various chemosynthetic ecosystems.

On the other hand, S. micheli and A. atlanteus mainly occurred at sites 2 and 3 . Within these sites, S. micheli showed highest abundance on bones, indicating a preference for organic substrata and associated bacterial mats. The dirivultid A. atlanteus showed highest abundance 


\section{ACCEPTED MANUSCRIPT}

at site 2 and decreased in density with decreasing temperature and fluid input. In contrast to $S$. micheli, A. atlanteus revealed no preference for a specific substratum type. Both species have been shown to be common in microhabitats associated with Bathymodiolus azoricus mussel assemblages around Eiffel Tower (Ivanenko et al. 2012, Sarrazin et al. 2015). They were also found in high densities on wood and slate panels in our previous colonization experiment (Cuvelier et al. 2014). Observations of S. micheli attached to filamentous microbial strains in mussel assemblages (pers. obs. C. Plum during MoMARSAT 2014) corroborate previous assumptions on their feeding ecology (Ivanenko et al. 2012), indicating a preference for microhabitats characterized by higher venting activity. In contrast to harpacticoid copepods, such as S. micheli, the Dirivultidae are considered as endemic for deep-sea hydrothermal vents since they are only known from this extreme ecosystem (Gollner et al. 2010b). Dirivultid copepods such as A. atlanteus have developed adaptations to cope with the high temperatures and toxic components of the vent fluids. They possess haemoglobins with a very high and temperature-sensitive oxygen affinity (Sell 2000, Gollner et al. 2011). In addition, they are specialized on food sources originating from local chemosynthetic production (Heptner and Ivanenko 2002, Gollner et al. 2006, Limén et al. 2008, De Busserolles et al. 2009), potentially explaining their high densities on substrata from sites 2 and 3. While dominating the active sites, both species were not restricted to those. At the inactive sites 4 and 5, A. atlanteus and S. micheli occurred on woods and slates, respectively, where the deployed substrata were surrounded by sediment, sulphide precipitations and bare basalt all devoid of invertebrate foundation species. Although their total abundance was very low at these sites with less than 10 individuals per species, their presence indicates that they can colonize areas with low fluid input, corroborating a recent study from the EPR where dirivultid copepods were found at about $1 \mathrm{~km}$ distance from any hydrothermal activity (Gollner et al. 2015a). Except for the previous LS colonization experiment described by Cuvelier et al. (2014), dirivultids were not described from organic hard substratum so far. 
Among the active sites, site 1 represents an exceptional case. Although the area was hydrothermally active, it showed rather moderate conditions compared to sites 2 and 3 . As a consequence, the substrata at site 1 harboured a very heterogeneous community with an overlap of species from high venting activity and inactive microhabitats. Although Tisbe sp. was not characterized as an indicator species due to its wide distribution at the LS vent field, its relative abundance and total density contributed to the similarity of site 1 (slate $\&$ bone) with sites 2 and 3. Among sites 3 and 1, Tisbe sp. revealed highest densities on the organic substrata, respectively woods and bones, as well as on wood of site 2 . This more or less corroborates the pattern observed in our previous colonization experiment at the LS vent field where Tisbe sp. occurred exclusively on wood panels (Cuvelier et al. 2014). The distinctive community composition on the site 1 wood panel strongly contributed to the higher similarity of this sample with slates of the inactive sites 4 and 5 . The variance in community composition between the substrata at site 1 might be attributed to the often observed smallscale spatial variability in physico-chemical conditions at hydrothermal vents (Sarrazin et al. 1997, 1999, 2015, Le Bris et al. 2006, Podowski et al. 2009). As a consequence, community colonization patterns can reveal high variability between closely spaced substrata. In addition, site 1 was characterized by the presence of a small active fissure, in the middle of a relatively inactive zone at the base of Eiffel Tower.

The inactive habitats were represented by the indicator species Bathylaophonte azorica and Ameiridae sp. 4. The first has been previously described from a hydrothermal vent on the MAR (Lee and Huys 1999) and the LS vent field (Cuvelier et al. 2014). In contrast, the Ameiridae is a widely distributed harpacticoid family with members found in deep-sea sediments and shallow-water habitats. Although they have been recorded at hydrothermal 


\section{ACCEPTED MANUSCRIPT}

vents and especially at LS (Cuvelier et al. 2014, Sarrazin et al. 2015), their presence is not very common. In addition to the Ameiridae, other harpacticoid families which are more common in non-vent, sedimentary deep-sea environments, such as Argestidae and Ectinosomatidae, revealed high abundance at the inactive sites. Their presence demonstrates that non-vent copepods exist in the close vicinity of hydrothermal vents. While the slate panels at the inactive sites showed a rather heterogeneous community with a high number of "rare" species, the wood substratum was clearly dominated by Nitocrella sp., indicating its preference for organic substrata in areas of low fluid input.

The observed patterns in species composition and diversity tend to correspond with the local environmental conditions, corroborating previous investigations demonstrating the influence of environmental factors such as temperature, sulphide and iron concentration, $\mathrm{pH}$ and oxygen content on the distribution of meiofaunal organisms at hydrothermal vents (Gollner et al. 2010a, Cuvelier et al. 2014, Sarrazin et al. 2015). Similar copepod distribution patterns, with dirivultid copepods dominating in high temperature microhabitats and harpacticoids being more prominent at moderate environmental conditions, have been described in previous meiofaunal studies (Gollner et al. 2010a, 2015a). Based on species distribution, the copepod assemblages can be separated into vent specialists represented by A. atlanteus and S. micheli, generalist species, showing a wide distribution across active and inactive habitats such as Nitocrella, Tisbe sp. and Miraciidae sp. 2 and non-vent species, represented by harpacticoids such as Ameiridae sp. 4., predominantly found in external areas characterized by bare basalts and sediments as well as moderate vent regimes. The observed changes of species composition along a gradient of physico-chemical variables may be the result of different species traits such as feeding preferences and adaptations to specific local environmental conditions. Besides the impact of abiotic environmental factors, other variables such as the available species pool of surrounding established populations, migration of neighbouring 


\section{ACCEPTED MANUSCRIPT}

populations, interspecific competition and predation may also contribute to the structure of the colonist assemblages (Cuvelier et al. 2014).

Our results further indicate that, on a local scale, organic hard substrata may serve as a suitable habitat for vent organisms that rely on chemosynthetic microorganisms as a primary food source. However, their importance for the dispersal of vent specific copepods is still poorly known. Based on findings of thousands of copepodites in the plume above a hydrothermal vent at the EPR, high dispersal abilities have been suggested for dirivultids which, consequently, may not rely on organic substrata as stepping stones to distribute along a spreading zone (Gollner et al. 2015a). Conversely, harpacticoid copepods are generally thought to have limited dispersal capabilities and thus may benefit from patches of organic hard substrata in the vicinity of hydrothermal vents. Whether small patches of organic hard substrata, such as wood falls and whale bones, surrounded by soft deep-sea sediments can be colonized by adult populations of vent specific copepods remains unknown and subject to further investigations.

\section{Copepod density}

Although total copepod density showed no significant differences between individual sites, mainly caused by the high variability between samples, it tends to increase with decreasing fluid input among the most active sites and to decrease with further decreasing fluid input . This pattern was especially pronounced on the wood and slate substrata while densities on bones continuously decreased with decreasing vent activity. The individual abundance of adults, copepodites and nauplii revealed the similar trends. The discovery of high abundance of juvenile copepod stages across the gradient in environmental conditions reflects observations recently reported from the Eiffel Tower edifice (Ivanenko et al. 2012, Sarrazin et al. 2015), and also contradict previous assumptions that copepod larval stages only inhabit 


\section{ACCEPTED MANUSCRIPT}

microhabitats outside the hydrothermal influence (Tsurumi et al. 2003). Thus, our experiment confirms that copepod communities can be well established in a variety of microhabitats and are capable to spend their whole life cycle under extreme conditions.

Our results showed significant differences in copepod density between substratum types mainly due to high densities on wood, particularly at sites with low hydrothermal influence. The observed patterns indicated a preference for organic substrata across the gradient of hydrothermal activity. At the active sites, densities were highest on bones and secondly, on wood panels. Conversely, results from our previous experiment at Eiffel Tower (but with $\mathrm{n}=$ 3 deployment sites compared to 5 here, and no inactive sites) reported no significant differences in overall faunal densities between wood and slate panels (Cuvelier et al. 2014). However, when extracting copepod densities from these data, the same trend is recovered, with higher densities on wood. Higher copepod densities on wood may result from increased niche heterogeneity due to the activity of wood boring bivalves, allowing colonization by smaller organisms. In addition, wood decomposition may produce significant concentrations of sulphides (Le Bris 2015, Kalenitchenko et al. 2015) that can be used by microbial mats, contributing to the resources available for copepods and other smaller taxa. Therefore, organic hard substrata might be suitable to provide living space for vent organisms with the nuance that very few vent "endemic" copepods were found outside the areas influenced by fluids, posing questions about the suitability of these substrata to facilitate copepod dispersal between adjacent hydrothermal systems.

Copepod densities observed on the substrata showed a wide range from 1.4 ind. $10 \mathrm{~cm}^{-2}$ to relatively high densities of up to 295 ind. $10 \mathrm{~cm}^{-2}$ (including copepodites). Lower copepod densities were found in our previous colonization experiment at Eiffel Tower $\left(9\right.$ ind. $10 \mathrm{~cm}^{-2}$; 


\section{ACCEPTED MANUSCRIPT}

Cuvelier et al. 2014), particularly on wood panels. Since this pilot study had a similar experimental setting, many factors such as substratum type, colonization surface and duration can be excluded to explain the observed differences. However, temporal and spatial changes in background communities and environmental conditions between the years of deployment (2006 in Cuvelier et al. 2014 and 2011 for the current study) may have triggered differences in copepod densities between the colonization experiments (Gauthier et al. 2010).

For a comparison, copepod densities reached values between 0.15 and 42 ind. $10 \mathrm{~cm}^{-2}$ in the nearby natural background mussel communities on the Eiffel Tower edifice (Sarrazin et al. 2015). Comparable copepod densities have been shown from the Riftia Field, the Tica and Buckfield hydrothermal vent sites at the East Pacific Rise (EPR), ranging from 0.19 to 29 ind. $10 \mathrm{~cm}^{-2}$ (Zekely et al. 2006b, Gollner et al. 2006, Gollner et al. 2007, Degen et al. 2012). Another study from the EPR (Guaymas) revealed copepod densities between 0.35 ind. $10 \mathrm{~cm}^{-2}$ and 60 ind. $10 \mathrm{~cm}^{-2}$ (Dinet et al. 1988). Densities reported from the Snake Pit vent site located at the MAR were within the same range showing highest values of 18 ind $10 \mathrm{~cm}^{-2}$ (Zekely et al. 2006). The highest copepod densities reported from hydrothermal vents $\left(470\right.$ ind. $\left.10 \mathrm{~cm}^{-2}\right)$ have been observed at the EPR in association with Alvinella pompejana polychaete communities and were mainly attributed to the highly adapted dirivultid copepod Stygiopontius hispidulus (Gollner et al. 2010a). Differences in copepod abundance may reflect the heterogeneity of environmental conditions at hydrothermal vents and at different spatial scales (Sarrazin et al. 2015). Other potential factors for the observed differences in densities may include competition, predation and physical disturbance as suggested in previous studies (reviewed by Olafsson 2003). However, to the best of our knowledge, the densities observed in our colonization experiment are the highest that have been reported from the LS vent field and among the highest values ever reported from hydrothermal vents. 


\section{Copepod diversity}

With a total of 45 species, we observed more copepod species in this colonization experiment than previously reported from the whole LS vent field (Van Dover and Trask 2000, Cuvelier et al. 2014, Sarrazin et al. 2015). These studies, including previous colonization experiments and ecological studies, documented between 3 and 11 copepod taxa from LS. Studies from other hydrothermal vents also reported lower copepod species richness from the Snake Pit vent field ( $\mathrm{S}=6$ ) on the MAR (Zekely et al. 2006), and between 14 to 27 species at the EPR (Zekely et al. 2006, Gollner et al. 2007, Gollner et al. 2010a). Differences in species richness might be related to a higher sampling effort and higher precision in taxonomic identification during the last decade. As a consequence, the estimates for meiofaunal diversity including copepod species richness at hydrothermal vents are constantly revised upwards (Van Dover 2000, Gollner et al. 2006, Gollner et al. 2010a, Cuvelier et al. 2014, Sarrazin et al. 2015). In addition, the inclusion of external sampling sites, which were characterized by relatively high numbers of "rare" species, may have contributed to the higher species richness described in our experiment. However, even when excluding the 12 species exclusively found at the inactive site, copepod species numbers still exceed those previously described for LS hydrothermal vents by 22 species.

Although the outcome of the statistical analysis revealed no significant difference in copepod diversity between individual sites and individual substrata, some interesting trends emerged. The observed patterns indicate an overall decrease of diversity with increasing temperature and fluid inputs, corroborating the results of our previous LS colonization experiments (Cuvelier et al. 2014, Zeppilli et al. 2015) and also, from other vent ecological studies (Tsurumi et al. 2003, Zekely et al. 2006, Gollner et al. 2010a, Ivanenko et al. 2012, Sarrazin et 


\section{ACCEPTED MANUSCRIPT}

al. 2015). The negative correlation between hydrothermal activity and taxonomical diversity is considered as typical in vent ecosystems (Sarrazin and Juniper 1999). Trends in copepod diversity are opposite to those of density as they show higher diversity on slates than on organic substrata across all sites, except for site 3, where total species richness (S) was lower on slates compared to the wood panel. The overall results contradict the outcome of the Cuvelier et al. study (2014) reporting higher faunal diversity on wood panels. Even after extracting the copepod data, their species richness was higher on woods at two out of the three sites (Cuvelier et al. 2014).

\section{Conclusion}

Although the limitations of the sampling design, such as a lack of replicates and statistical significances, may limit the interpretation of the results, the outcome of our study represents the most comprehensive investigation of the copepod fauna from the LS vent field and provides answers to our initial research questions.

1) The substratum type had a significant impact on copepod density, although the pattern varied across the gradient in fluid input (Fig. 6). Copepod densities at the most active sites were highest on bones while wood revealed higher densities with further decreasing temperature and fluid input. While showing lowest densities, slates exhibited highest absolute copepod diversity across the gradient in hydrothermal activity.

2) The abiotic conditions were of minor importance to explain copepod abundance but showed an overall effect on copepod diversity which increased with decreasing hydrothermal activity corroborating previous findings that demonstrate the negative correlation between local environmental conditions and meiofaunal diversity patterns (Fig. 6). In addition, species composition was significantly influenced by temperature 


\section{ACCEPTED MANUSCRIPT}

and fluid input rather than the substratum type (Fig. 6). Thus, our experiment indicates that physico-chemical conditions are important drivers of copepod colonization patterns at hydrothermal vents, corroborating previous studies on the impact of environmental conditions on the distribution of vent meiofauna. We suggest that this may be linked to the presence of different species traits such as nutritional requirements and adaptation to local environmental conditions resulting in diverging microhabitat preferences.

3) At the same time, our experiment supports previous suggestions for the existence of specific vent habitats inhabited by indicator species that reflect both, differences in environmental conditions and the species pool of established background communities.

The outcome of our study provides a detailed insight into the copepod community composition around the Eiffel Tower edifice and strongly contributes to the evaluation of spatial and temporal patterns of meiofaunal communities at hydrothermal vents in relation to local environmental drivers.

\section{Acknowledgements}

Special thanks to the captains and crews of the R/V Pourquoi Pas? and the pilots of the Victor6000 ROV for their great support during the MoMARSAT and BIOBAZ cruises. We are also very grateful to the LEP technical and engineering teams for their support at sea and in the laboratory. In addition we would like to thank Prof. V.N. Ivanenko for his support in species identification and Dr. S. Gollner for fruitful discussions on vent copepod distribution. This work was supported by the "Laboratoire d'Excellence" LabexMER (ANR-10-LABX-19) and co-funded by a grant from the French government under the program" Investissements d'Avenir and is part of the EMSO-Acores research program funded by an ANR research grant (ANR Lucky Scales ANR-14-CE02-0008-02). The project has also received funding from the 


\section{ACCEPTED MANUSCRIPT}

European Union Seventh Framework Programme (FP7/2007-2013) under the MIDAS project, grant agreement $n^{\circ} 603418$.

\section{References}

Bennett, S. A., Hansman, R. L., Sessions, A. L., Edwards, K. J., 2011. Tracing iron-fueled microbial carbon production within the hydrothermal plume at the Loihi seamount. Geochimica et Cosmochimica Acta 75:5526-5539.

Bienhold, C., Ristova, P. P., Wenzhöfer, F., Dittmar, T., Boetius, A., 2013. How deep-sea wood falls sustain chemosynthetic life. PLoS one 8:e53590.

Böggemann, M., Bienhold, C., Gaudron, S. M., 2012. A new species of Glyceridae (Annelidae: „Polychaeta”) recovered from organic substrate experiments at the cold seeps in the eastern Mediterranean Sea. Marine Biodiversity 42:47-54

Boxshall, G., Halsey, S. H., 2004. An introduction to copepod diversity. Ray Society, London

Charlou, J. L., Donval, J. P., Douville, E., Jean-Baptiste, P., Radford-Knoery, J., Fouquet, Y., Dapoigny, A., Stievenard, M., 2000. Compared geochemical signatures and the evolution of Menez Gwen $\left(37^{\circ} 50^{\prime} \mathrm{N}\right)$ and Lucky Strike $\left(37^{\circ} 17^{\prime} \mathrm{N}\right)$ hydrothermal fluids, south of the Azores Triple Junction on the Mid-Atlantik Ridge. Chemical Geology 171: $49-75$

Childress, J. J., Fisher, C. R.m 1992. The biology of hydrothermal vent animals: physiology, biogeochemistry and autotrophic symbiosis. Oceanography and Marine Biology Annual Review 30: 337-441

Clark, M. R., OShea, S. 2001. Hydrothermal vent and seamount fauna from the southern Kermadec Ridge, New Zealand. Inter-Ridge News 10: 14-17.

Clarke, K., and Gorley, G. R., 2006. V6: user manual/tutorial. Primer-E Ltd. Plymouth.-2006. 


\section{ACCEPTED MANUSCRIPT}

Copley, J. T. P., Flint, H. C., Ferrero, T. J., and Van Dover, C. L., 2007. Diversity of meiofauna and free-living nematodes in hydrothermal vent mussel beds on the northern and southern East Pacific Rise. Journal of the Marine Biological Association of the United Kingdom 87:1141-1152.

Cuvelier, D., Sarrazin, J., Colaço, A., Copley, J., Desbruyères, D., Glover, A. G., Tyler, P., Santos, R. S., 2009. Distribution and spatial variation of hydrothermal faunal assemblages at Lucky Strike (Mid-Atlantic Ridge) revealed by high-resolution video image analysis. Deep Sea Research Part I: Oceanographic Research Papers 56:20262040 .

Cuvelier, D., De Busserolles, F., Lavaud, R., Floc'h, E., Fabri, M.-C., Sarradin, P.-M., Sarrazin, J., 2012. Biological data extraction from imagery-How far can we go? A case study from the Mid-Atlantic Ridge. Marine environmental research 82:15-27.

Cuvelier, D., Beesau, J., Ivanenko, V. N., Zeppilli, D., Sarradin, P.-M., Sarrazin, J., 2014. First insights into macro-and meiofaunal colonisation patterns on paired wood/slate substrata at Atlantic deep-sea hydrothermal vents. Deep Sea Research Part I: Oceanographic Research Papers 87:70-81.

Danovaro, R. 2009. Methods for the study of deep-sea sediments, their functioning and biodiversity. CRC Press.

De Busserolles, F., Sarrazin, J., Gauthier, O., Gélinas, Y., Fabri, M. C., Sarradin, P. M., Desbruyères, D., 2009. Are spatial variations in the diets of hydrothermal fauna linked to local environmental conditions? Deep Sea Research Part II: Topical Studies in Oceanography 56:1649-1664.

De Cáceres, M., Legendre, P., 2009. Associations between species and groups of sites: indices and statistical inference. Ecology 90, 3566-3574. 


\section{ACCEPTED MANUSCRIPT}

De Cáceres, M., Jansen, F., 2011. Indicspecies: Functions to assess the strenght and significance of relationships of species site group associations. R package version 1.6.0.

Degen, R., Riavitz, L., Gollner, S., Vanreusel, A., Plum, C., Bright, M., 2012. Community study of tubeworm-associated epizooic meiobenthos from deep-sea cold seeps and hot vents. Marine Ecology Progress Series 468:135-148.

Desbruyères, D., Biscoito, M., Caprais, J.-C., Colaço, A., Comtet, T., Crassous, P., Fouquet, Y., Khripounoff, A., Le Bris, N., Olu ,K., 2001. Variations in deep-sea hydrothermal vent communities on the Mid-Atlantic Ridge near the Azores plateau. Deep Sea Research Part I: Oceanographic Research Papers 48:1325-1346.

Dinet, A., Grassle, F., Tunnicliffe, V., 1988. First observations on the meiofauna from hydrothermal vents of the East Pacific Rise (Guaymas, 21[degree]N) and Explorer Ridge. Oceanologica Acta Special Issue 8:7-14.

Distel, D. L., Baco, A. R., Chuang, E., Morrill, W., Cavanaugh, C., Smith, C. R., 2000. Marine ecology: Do mussels take wooden steps to deep-sea vents? Nature 403:725726.

Dubilier, N., Bergin, C., Lott, C., 2008. Symbiotic diversity in marine animals: the art of harnessing chemosynthesis. Nat Rev Microbiol 6: 725-740.

Gaudron, S., Pradillon, F., Pailleret, M., Duperron, S., Le Bris, N., Gaill, F., 2010. Colonization of organic substrates deployed in deep-sea reducing habitats by symbiotic species and associated fauna. Marine environmental research 70:1-12.

Gauthier, O., Sarrazin, J., Desbruyères, D., 2010. Measure and mis-measure of species diversity in deep-sea chemosynthetic communities. Marine Ecology Progress Series 402:285-302.

German, C. R., Parson L. M., Bougault F., Coller D., Critchley M., Dapoigny A., Day C., Eardley D., Fearn A., Flewellen C., Kirk R., Klinkhammer G., Landure J. Y., Ludford 


\section{ACCEPTED MANUSCRIPT}

E., Miranda M., Needham H. D., Patching J., Pearce R., Pelle H., Radfordknoery J., Rouse I., Scott J., Stoffregen P., Taylor P., Teare D., Wynar J., 1996. Hydrothermal exploration near the Azores Triple Junction: tectonic control of venting at slowspreading ridges? Earth Planet Science Letter 138:93-104.

Giere, O., 2013. Meiobenthology: the microscopic fauna in aquatic sediments. Springer Science \& Business Media.

Gollner, S., Zekely, J., Van Dover, C. L., Govenar, B., Nemeschkal, H. L., Bright, M., 2006. Benthic copepod communities associated with tubeworm and mussel aggregations on the East Pacific Rise. Cahiers de biologie marine 47:397-402.

Gollner, S., Zekely, J., Govenar, B., Le Bris, N., Nemeschkal, H. L., Fisher, C. R. , Bright, M., 2007. Tubeworm-associated permanent meiobenthic communities from two chemically different hydrothermal vent sites on the East Pacific Rise. Marine Ecology Progress Series 337:39-49.

Gollner, S., Ivanenko, V. N., Arbizu, P. M., 2008. A new species of deep-sea Tegastidae (Crustacea : Copepoda : Harpacticoida) from 9 degrees 50 ' $\mathrm{N}$ on the East Pacific Rise, with remarks on its ecology. Zootaxa:323-336.

Gollner, S., Riemer, B., Martinez-Arbizu, P., Le Bris, N., Bright, M., 2010a. Diversity of meiofauna from the $950^{\prime} \mathrm{N}$ East Pacific Rise across a gradient of hydrothermal fluid emissions. PLoS one 5:e12321.

Gollner, S., Ivanenko, V. N., Martinez Arbizu, P., Bright, M., 2010b. Advances in taxonomy, ecology, and biogeography of Dirivultidae (Copepoda) associated with chemosynthetic environments in the deep sea. PLoS one 5:e9801.

Gollner, S., Fontaneto, D., Arbizu, P. M., 2011. Molecular taxonomy confirms morphological classification of deep-sea hydrothermal vent copepods (Dirivultidae) and suggests broad physiological tolerance of species and frequent dispersal along ridges. Marine Biology 158:221-231. 


\section{ACCEPTED MANUSCRIPT}

Gollner, S., Miljutina, M., Bright, M., 2013. Nematode succession at deep-sea hydrothermal vents after a recent volcanic eruption with the description of two dominant species. Organisms Diversity \& Evolution 13:349-371.

Gollner, S., Govenar, B., Martinez Arbizu, P., Mills, S., Le Bris, N., Weinbauer, M., Shank, T. M., Bright, M., 2015a. Differences in recovery between deep-sea hydrothermal vent and vent-proximate communities after a volcanic eruption. Deep-Sea Research I 106: 167-182.

Gollner, S., Govenar, B., Fisher, C. R., Bright, M., 2015b. Size matters at deep-sea hydrothermal vents: different diversity and habitat fidelity patterns of meio-and macrofauna. Mar Ecol Prog Ser 520:57-66.

Govenar, B., Le Bris, N., Gollner, S., Glanville, J., Aperghis, A. B., Hourdez, S., Fisher, C. R., 2005. Epifaunal community structure associated with Riftia pachyptila aggregations in chemically different hydrothermal vent habitats. Marine Ecology Progress Series 305:67-77.

Heptner, M. V., Ivanenko, V. N., 2002. Copepoda (Crustacea) of hydrothermal ecosystems of the World Ocean. Arthropoda Selecta 11:117-134.

Hicks, G. R., 1988. Systematics of the donsiellinae lang (Copepoda, Harpacticoida). Journal of Natural History 22:639-684.

Hilario, A., Cunha, M. R., Génio, L., Raquel Marçal, A., Ravara, A., Rodrigues, C. F., Wiklund, H., 2015. First clues on the ecology of whale falls in the deep Atlantic Ocean: results from an experiment using cow carcasses. Marine Ecology doi: 10.1111/maec. 12246

Hulbert, S. H., 1971. The non-concept of species diversity: a critique and alternative parameter. Ecology 52: 577-586.

Humes, A. G., Huys, R., 1992. Copepoda (Poecilostomatoida and Siphonostomatoida) from deep-sea hydrothermal vent areas off British Columbia, including Amphicrossus 


\section{ACCEPTED MANUSCRIPT}

altalis, a new species of Erebonasteridae, with notes on the taxonomic position of the genus Tychidion Humes. Canadian Journal of Zoology 70:1369_/80.

Humphris, S. E., Fornari, D. J., Scheirer, D. S., German, C. R., Parson, L. M., 2002. Geotectonic setting of hydrothermal activity on the summit of Lucky Strike Seamount (37 17' N, Mid-Atlantic Ridge). Geochemistry, Geophysics, Geosystems 3:1-25.

Huys, R., 1991. Crustacea Copepoda: Amphicrossus pacificus gen. et sp. nov., an erebonasterid copepod (Poecilostomatoida) from the New Caledonian continental shelf. Mémoires du Muséum National d'Histoire Naturelle, Paris, Série A, Zoologie 152:63-77

Ivanenko, V. N., Defaye, D., 2004. A new genus and species of deep-sea cyclopoid (Crustacea, copepoda, cyclopinidae) from the Mid-Atlantic Ridge (Azores Triple Junction, Lucky Strike). Zoosystema 26:49-64.

Ivanenko, V. N., Defaye, D., Huys, R., 2005. A new species of Ambilimbus nom. nov., a replacement name for Amphicrossus Huys, 1991 (Copepoda, Cyclopoida, Erebonasteridae), from the Mid_Atlantic Ridge at $36^{\circ} \mathrm{N}$ (hydrothermal vent site Rainbow). Marine Biology Research 1:233-241

Ivanenko, V. N., Martinez-Arbizu, P., Stecher, J., 2006. Copepods of the family Dirivultidae (Siphonostomatoida) from deep-sea hydrothermal vent fields on the Mid-Atlantic Ridge at $14^{\circ} \mathrm{N}$ and $5^{\circ} \mathrm{S}$. Zootaxa 1277:1-21.

Ivanenko, V. N., Ferrari, F. D., Defaye, D., Sarradin, P. M., Sarrazin, J., 2011. Description, distribution and microhabitats of a new species of Tisbe (Copepoda: Harpacticoida: Tisbidae) from a deep-sea hydrothermal vent field at the Mid-Atlantic Ridge $\left(37^{\circ} \mathrm{N}\right.$, Lucky Strike). Cahiers de biologie marine 52:361-361.

Ivanenko, V. N., Corgosinho, P. H., Ferrari, F., Sarradin, P. M., Sarrazin, J., 2012. Microhabitat distribution of Smacigastes micheli (Copepoda: Harpacticoida: Tegastidae) from deep-sea hydrothermal vents at the Mid-Atlantic Ridge, $37^{\circ} \mathrm{N}$ 


\section{ACCEPTED MANUSCRIPT}

(Lucky Strike), with a morphological description of its nauplius. Marine Ecology 33:246-256.

Kalenitchenko, D., Fagervold, S. K., Prunksi, A. M., Vétion, G., Yücel, M., Le Bris, N., Galand, P. E., 2015. Temporal and spatial constrains on community assembly during microbial colonization of wood in seawater. ISME Journal 9:2657-2670

Karl, D. M. 1995. Ecology of free-living, hydrothermal vent microbial communities. In: Karl DM, ed. Microbiology of extreme and unusal environments. New York: CRS Press. pp 35-124.

Kelly, N., Metaxas, A., Butterfield, D., 2007. Spatial and temporal patterns of colonization by deep-sea hydrothermal vent invertebrates on the Juan de Fuca Ridge, NE Pacific. Aquatic Biology 1:1-16.

Kelly, N., Metaxas, A., 2008. Diversity of invertebrate colonists on simple and complex substrates at hydrothermal vents on the Juan de Fuca Ridge. Aquatic Biology 3:271281.

Lebreton, B., Richard, P., Galois, R., Radenac, G., Brahmia, A., Colli, G., Grouazel, M., André, C., Guillou, G., Blanchard, G. F., 2012. Food sources used by sediment meiofauna in an intertidal Zostera noltii seagrass bed: a seasonal stable isotope study. Marine Biology 159:1537-1550.

Le Bris, N., Govenar, B., Le Gall, C., Fisher, C. R., 2006. Variability of physico-chemical conditions in 9 degrees 50 'N EPR diffuse flow vent habitats. Marine Chmistry 98: $167-182$

Lee, W., Huys, R., 1999. Bathylaophonte gen. nov. from deep-sea hydrothermal vents and the polyphyly of Paronychocamptus (Copepoda: Harpacticoida). Cah. Biol. Mar. 40:293 328

Legendre, P., Gallagher, E. D., 2001. Ecologically meaningful transformations for ordination of species data. Oecologia 129: 271-280. 


\section{ACCEPTED MANUSCRIPT}

Legendre, P., Legendre, L., 2012. Numerical Ecology, $3^{\text {rd }}$ Edn. Elsevier, Amsterdam.

Levesque, C., Juniper, S. K., Marcus, J., 2003. Food resource partitioning and competition among alvinellid polychaetes of Juan de Fuca Ridge hydrothermal vents. Marine Ecology Progress Series 246:173-182.

Limén, H., Stevens, C., Bourass, Z., Juniper, S. K., 2008. Trophic ecology of siphonostomatoid copepods at deep-sea hydrothermal vents in the northeast Pacific. Marine Ecology Progress Series 359:161.

Marcus, J., Tunnicliffe, V., Butterfield, D. A., 2009. Post-eruption succession of macrofaunal communities at diffuse flow hydrothermal vents on Axial Volcano, Juan de Fuca Ridge, Northeast Pacific. Deep Sea Research Part II: Topical Studies in Oceanography 56:1586-1598.

Martínez-Arbizu, P., 1999. New Erebonasteridae (Copepoda) from Vilkitzky Strait in the Arctic and from a Pacific hydrothermal vent site (northern Fiji Basin). Journal of Crustacean Biology 19:93-105.

Mullineaux, L. S., Mills, S. W., Goldman, E., 1998. Recruitment variation during a pilot colonization study of hydrothermal vents (9 50' N, East Pacific Rise). Deep Sea Research Part II: Topical Studies in Oceanography 45:441-464.

Mullineaux, L. S., Peterson, C. H., Micheli, F., Mills, S. W., 2003. Successional mechanism varies along a gradient in hydrothermal fluid flux at deep-sea vents. Ecological monographs 73:523-542.

Mullineaux, L. S., Le Bris, N., Mills, S. W., Henri, P., Bayer, S. R., Secrist, R. G., Siu, N., 2012. Detecting the influence of initial pioneers on succession at deep-sea vents. PLoS one 7:e50015.

Olafsson, E., 2003. Do macrofauna structure meiofauna assemblages in marine soft bottoms? Vie et milieu 53:249. 


\section{ACCEPTED MANUSCRIPT}

Plum, C., Gollner, S., Martínez-Arbizu, P., Bright, M., 2015. Diversity and composition of the copepod communities associated with megafauna around a cold seep in the Gulf of Mexico with remarks on species biogeography. Mar Biodiv 45:419-432

Podowski, E. L., Moore, T. S., Zelnio, K. A., Luther, G. W., Fisher, C. R., 2009. Distribution of diffuse flow megafauna in two sites on the Eastern Lau Spreading Center. Tonga. Deep-Sea Research Part I 56:2041-2056.

Pradillon, F., Zbinden, M., Mullineaux, L. S., Gaill, F., 2005. Colonisation of newly-opened habitat by a pioneer species, Alvinella pompejana (Polychaeta: Alvinellidae), at East Pacific Rise vent sites. Marine Ecology Progress Series 302:147-157

Pradillon, F., Zbinden, M., Le Bris, N., Hourdez, S., Barnay, A.-S., Gaill, F., 2009. Development of assemblages associated with alvinellid colonies on the walls of hightemperature vents at the East Pacific Rise. Deep Sea Research Part II: Topical Studies in Oceanography 56:1622-1631.

Sarradin, P.-M., Waeles, M., Bernagout, S., Le Gall, C., Sarrazin, J., Riso, R., 2009. Speciation of dissolved copper within an active hydrothermal edifice on the Lucky Strike vent field (MAR, 37 N). Science of the Total Environment 407:869-878.

Sarrazin, J., robigou, V., Juniper, S. K., Delaney, J. R., 1997. Biological and geological dynamics over four years on a high-temperature sulfide structure at the Juan de Fuca Ridge hydrothermal observatory. Marine Ecology Progress Series 153: 5-24.

Sarrazin, J., Juniper, S. K., 1999. Biological cahracteristics of a hydrothermal edifice mosaic community. Marine Ecological Progress Series 185: 1-19.

Sarrazin, J., Cuvelier, D., Peton, L., Legendre, P., Sarradin, P.-M., 2014. High-resolution dynamics of a deep-sea hydrothermal mussel assemblage monitored by the EMSOAçores MoMAR observatory. Deep Sea Research Part I: Oceanographic Research Papers 90:62-75. 


\section{ACCEPTED MANUSCRIPT}

Sarrazin, J., Legendre, P., De Busserolles, F., Fabri, M.-C., Guilini, K., Ivanenko, V. N., Morineaux, M., Vanreusel, A., Sarradin, P.-M., 2015. Biodiversity patterns, environmental drivers and indicator species on a high-temperature hydrothermal edifice, mid-Atlantic ridge. Deep Sea Research Part II: Topical Studies in Oceanography.

Shank, T. M., Fornari, D. J., Von Damm, K. L., Lilley, M. D., Haymon, R. M., Lutz, R. A., 1998. Temporal and spatial patterns of biological community development at nascent deep-sea hydrothermal vents (9 50' N, East Pacific Rise). Deep-Sea Research Part II 45:465-515.

Shirayama, Y., 1992. Studies of meiofauna collected from the Iheya Ridge during the dive 541 of the" SHINKAI 2000". JAMSTEC Deep Sea Research. 8:287-291.

Smith, C., Kukert, H., 1989. Vent fauna on whale remains. Nature 341:27-28.

Szafranski, K. M., Deschamps, P., Cunha, M. R., Gaudron, S. M., Duperron, S., 2015. Colonization of plant substrates at hydrothermal vents and cold seeps in the northeast Atlantic and Mediterranean and occurrence of symbiont-related bacteria. Frontiers in Microbiology 6.

Tsurumi, M., Tunnicliffe, V., 2001. Characteristics of a hydrothermal vent assemblage on a volcanically active segment of Juan de Fuca Ridge, northeast Pacific. Canadian Journal of Fisheries and Aquatic Sciences 58:530-542.

Van Dover, C. L., 2000. The ecology of deep-sea hydrothermal vents. Princeton University Press.

Van Dover, C. L., 2014. Impacts of anthropogenic disturbances at deep-sea hydrothermal vent ecosystems: A review. Marine Environmental Research 102:59-72.

Van Dover, C. L., Berg, C. J., Turner, R. D., 1988. Recruitment of marine invertebrates to hard substrates at deep-sea hydrothermal vents on the East Pacific Rise and Galapagos 


\section{ACCEPTED MANUSCRIPT}

spreading center. Deep Sea Research Part A. Oceanographic Research Papers 35:1833-1849.

Van Dover, C. L., Desbruyères, D., Segonzac, M., Comtet, T., Saldanha, L., Fiala-Medioni, A., Langmuir, C., 1996. Biology of the Lucky Strike hydrothermal field. Deep Sea Research Part I: Oceanographic Research Papers 43:1509-1529.

Van Dover, C.L., Trask, J. L., 2000. Diversity at deep-sea hydrothermal vent and intertidal mussel beds. Marine Ecology Progress Series 195: 169-178

Von Damm, K. L., Bray, A. M., Buttermore, L. G., Oosting, S. E., 1998. The geochemical controls on vent fluids from the Lucky Strike vent field, Mid-Atlantic Ridge. Earth and Planetary Science Letters 160; 521.

Vrijenhoek, R. C., 2010. Genetic diversity and connectivity of deep-sea hydrothermal vent metapopulations. Molecular Ecology 19:4391-4411.

Zekely, J., Gollner, S., Van Dover, C. L., Govenar, B., Le Bris, N., Nemeschkal, H. L., Bright, M., 2006a. Nematode communities associated with tubeworm and mussel aggregations on the East Pacific Rise. Cah. Biol. Mar 47:477-482.

Zekely, J., Van Dover, C. L., Nemeschkal, H. L., Bright. M., 2006b. Hydrothermal vent meiobenthos associated with mytilid mussel aggregations from the Mid-Atlantic Ridge and the East Pacific Rise. Deep-Sea Research Part I-Oceanographic Research Papers 53:1363-1378.

Zeppilli, D., Vanreusel, A., Pradillon, F., Fuchs, S., Mandon, P., James, T., Sarrazin, J., 2015. Rapid colonisation by nematodes on organic and inorganic substrata deployed at the deep-sea Lucky Strike hydrothermal vent field (Mid-Atlantic Ridge). Marine Biodiversity 45:489-504.

Zielinski, F. U., Gennerich, H. H., Borowski, C., Wenzhöfer, F., Dubilier, N., 2011. In situ measurements of hydrogen sulfide, oxygen, and temperature in diffuse fluids of an ultramafic-hosted hydrothermal vent field (Logatchev, $14^{\circ} 45^{\prime} \mathrm{N}$, Mid-Atlantic 
Ridge): Implications for chemosymbiotic bathymodiolin mussels. Geochemistry,

\section{Geophysics, Geosystems 12.}

Table 1. Site number ranked by emission level, coordinates, depth, temperature and fluid input in percentage at all sampling

sites at the Eiffel Tower edifice. Abbreviations: Avg. $=$ average, $\mathrm{T}^{\circ} \mathrm{C}=$ temperature in Celsius, Min. $=$ minimum, Max. $=$ maximum, $\mathrm{STD}=$ standard deviation, fluid input $\%=0.314 * \mathrm{~T}-1.38$ (see Material and Methods, Environmental conditions, for further explanation).

\begin{tabular}{clcccccccc}
\hline $\begin{array}{c}\text { Sit } \\
\mathrm{e}\end{array}$ & Emission & $\begin{array}{c}\text { Latitude } \\
\mathrm{N}\end{array}$ & $\begin{array}{c}\text { Longitude } \\
\mathrm{W}\end{array}$ & $\begin{array}{c}\text { Depth } \\
(\mathrm{m})\end{array}$ & $\begin{array}{c}\text { Avg. } \\
\mathrm{T}^{\circ} \mathrm{C}\end{array}$ & $\begin{array}{c}\text { Min. } \\
\mathrm{T}^{\circ} \mathrm{C}\end{array}$ & $\begin{array}{c}\text { Max. } \\
\mathrm{T}{ }^{\circ} \mathrm{C}\end{array}$ & $\begin{array}{c}\text { ST } \\
\mathrm{D}\end{array}$ & Fluid input (\%) \\
\hline \hline 2 & High & $37^{\circ} 17.35$ & $32^{\circ} 16.53$ & 1699 & 7.26 & 4.45 & 21.60 & 1.56 & 0.90 \\
3 & $\begin{array}{l}\text { Intermediat } \\
\mathrm{e}\end{array}$ & $37^{\circ} 17.34$ & $32^{\circ} 16.54$ & 1698 & 5.48 & 4.32 & 12.20 & 0.55 & 0.34 \\
1 & Low & $37^{\circ} 17.33$ & $32^{\circ} 16.53$ & 1695 & 4.80 & 4.36 & 5.42 & 0.12 & 0.13 \\
4 & External & $37^{\circ} 17.32$ & $32^{\circ} 16.53$ & 1701 & 4.74 & 4.38 & 5.10 & 0.13 & 0.11 \\
5 & Non-active & $37^{\circ} 17.47$ & $32^{\circ} 16.80$ & 1741 & 4.55 & 4.32 & 4.77 & 0.07 & 0.05 \\
\hline
\end{tabular}

Table 2. Copepod density (including copepodites) and diversity of the different substrata deployed at five stations. Copepod diversity is given as species richness (S) and the expected species number ES (100).

Sample for the bone substratum was not available (n.a.) at station 5.

\begin{tabular}{|c|c|c|c|c|c|c|c|}
\hline Site & Emission & Substratum & Code & $\begin{array}{c}\text { Density } \\
\text { (ind. } \mathrm{cm}^{-2} \text { ) }\end{array}$ & $\begin{array}{c}\text { Density } \\
\left(\ln \text { ind. } \mathrm{cm}^{-2}\right)\end{array}$ & $\mathrm{S}$ & ES (100) \\
\hline \multirow[t]{3}{*}{2} & High & Slate & A2 & 3.27 & 1.19 & 13 & 7 \\
\hline & & Wood & B2 & 7.93 & 2.07 & 7 & 5 \\
\hline & & Bone & $\mathrm{C} 2$ & 40.42 & 3.70 & 10 & 7 \\
\hline \multirow[t]{3}{*}{3} & Intermediate & Slate & A3 & 10.25 & 2.33 & 12 & 6 \\
\hline & & Wood & B3 & 15.76 & 2.76 & 14 & 5 \\
\hline & & Bone & $\mathrm{C} 3$ & 32.65 & 3.49 & 8 & 5 \\
\hline \multirow[t]{3}{*}{1} & Low & Slate & A1 & 5.57 & 1.72 & 20 & 11 \\
\hline & & Wood & B1 & 294.29 & 5.68 & 16 & 10 \\
\hline & & Bone & $\mathrm{C} 1$ & 15.78 & 2.76 & 14 & 9 \\
\hline \multirow[t]{3}{*}{4} & External & Slate & A4 & 3.38 & 1.22 & 13 & 13 \\
\hline & & Wood & B4 & 104.32 & 4.65 & 13 & 5 \\
\hline & & Bone & $\mathrm{C} 4$ & 1.40 & 0.34 & 8 & 7 \\
\hline \multirow[t]{3}{*}{5} & Non-active & Slate & A5 & 3.08 & 1.13 & 31 & 24 \\
\hline & & Wood & B5 & 92.21 & 4.52 & 12 & 5 \\
\hline & & Bone & $\mathrm{C} 5$ & n.a. & n.a. & n.a. & n.a. \\
\hline
\end{tabular}


Table 3. Species-site-matrix showing densities (ind. $10 \mathrm{~cm}^{-2}$ ) for all copepod species collected from samples of three different substrata deployed at five sites along a

gradient of hydrothermal activity. Highest abundance per sample are indicated by bold numbers. For abbreviations see Table 2 .

\begin{tabular}{|c|c|c|c|c|c|c|c|c|c|c|c|c|c|c|c|}
\hline \multirow[b]{2}{*}{ Species } & \multicolumn{3}{|c|}{ High } & \multicolumn{3}{|c|}{ Intermediate } & \multicolumn{3}{|c|}{ Low } & \multicolumn{3}{|c|}{ External } & \multicolumn{3}{|c|}{ Inactive } \\
\hline & A2 & B2 & $\mathrm{C} 2$ & A3 & B3 & C3 & A1 & B1 & C1 & A4 & B4 & C4 & A5 & B5 & C5 \\
\hline Order CALANOIDA & & & & & & & & & & & & & & & \\
\hline Calanoida sp. 1 & 0 & $\begin{array}{r}0.0 \\
03\end{array}$ & 0 & 0 & 0 & 0 & $\begin{array}{r}0.0 \\
06\end{array}$ & 0 & 0 & 0 & 0 & 0 & $\begin{array}{r}0.0 \\
23 \\
0.0\end{array}$ & $\begin{array}{r}0.00 \\
4\end{array}$ & n.a. \\
\hline $\begin{array}{l}\text { Calanoida sp. } 2 \\
\text { Order } \\
\text { CYCLOPOIDA }\end{array}$ & 0 & 0 & 0 & 0 & 0 & 0 & 0 & 0 & 0 & 0 & 0 & 0 & 12 & 0 & \\
\hline Family Cyclopinidae & 0.2 & & 0.80 & 0.3 & 0.01 & 0.10 & 1.2 & & 0.0 & & & 0.0 & 0.0 & & \\
\hline $\begin{array}{l}\text { Heptnerina confusa } \\
\text { Order Harpacticoida } \\
\text { Familiy Ameiridae }\end{array}$ & 39 & 0 & 0 & 31 & 7 & 5 & 31 & 0.051 & 57 & 0 & 0 & 29 & 12 & 0 & \\
\hline Ameira longipes & $\begin{array}{r}0 \\
0.0\end{array}$ & 0 & $\begin{array}{r}0.72 \\
1\end{array}$ & $\begin{array}{r}0.0 \\
30 \\
0.0\end{array}$ & 0 & 0 & $\begin{array}{r}0.1 \\
21 \\
0.6\end{array}$ & $\begin{array}{r}17.04 \\
0\end{array}$ & $\begin{array}{r}0.0 \\
75 \\
1.2\end{array}$ & $\begin{array}{r}\mathbf{0 . 4} \\
\mathbf{7 7} \\
0.0\end{array}$ & $\begin{array}{r}0 \\
0.11\end{array}$ & 0 & $\begin{array}{r}0.1 \\
23\end{array}$ & $\begin{array}{r}0.04 \\
0 \\
0.55\end{array}$ & \\
\hline $\begin{array}{l}\text { Ameiropsis mixta } \\
\text { Paraleptopseudomesoc }\end{array}$ & 17 & 0 & 0 & 12 & 0 & 0 & 82 & 0 & 53 & 29 & 2 & 0 & $\begin{array}{r}0 \\
0.0\end{array}$ & 1 & \\
\hline hra sp & 0 & 0 & 0 & 0 & $\begin{array}{r}0 \\
2.30\end{array}$ & 0 & 0 & & 0 & 0 & 0 & $\begin{array}{r}0 \\
0.0\end{array}$ & $\begin{array}{r}12 \\
0.0\end{array}$ & 0 & \\
\hline Nitocra sp. & 0 & 0 & 0 & 0 & 4 & 0 & $\begin{array}{l}0 \\
0.0\end{array}$ & $\begin{array}{l}6.296 \\
26.60\end{array}$ & 0 & $\begin{array}{r}0 \\
0.3\end{array}$ & 0 & 12 & $\begin{array}{r}70 \\
0.0\end{array}$ & 0 & \\
\hline Haifamera sp. & $\begin{array}{r}0 \\
0.0\end{array}$ & $\begin{array}{r}0 \\
0.2\end{array}$ & $\begin{array}{r}0 \\
3.18\end{array}$ & 0 & $\begin{array}{r}0 \\
0.06\end{array}$ & $\begin{array}{r}0 \\
2.40\end{array}$ & $\begin{array}{r}12 \\
0.0\end{array}$ & $\begin{array}{r}6 \\
68.08\end{array}$ & $\begin{array}{r}0 \\
1.4\end{array}$ & $\begin{array}{r}05 \\
0.3\end{array}$ & $\begin{array}{r}0 \\
\mathbf{5 2 . 0}\end{array}$ & $\begin{array}{r}0 \\
0.0\end{array}$ & $\begin{array}{r}41 \\
0.2\end{array}$ & $\begin{array}{r}0 \\
45.6\end{array}$ & \\
\hline Nitocrella sp. & 06 & 89 & 6 & 0 & 8 & 7 & 35 & 4 & $\begin{array}{r}68 \\
0.0\end{array}$ & $\begin{array}{r}87 \\
0.1\end{array}$ & 33 & 35 & $\begin{array}{r}58 \\
0.0\end{array}$ & 91 & \\
\hline Ameiridae sp. 3 & 0 & 0 & 0 & 0 & $\begin{array}{r}0 \\
0.11\end{array}$ & 0 & $\begin{array}{r}0 \\
0.0\end{array}$ & 0 & 04 & 15 & $\begin{array}{r}0 \\
1.00\end{array}$ & $\begin{array}{r}0 \\
0.1\end{array}$ & $\begin{array}{r}06 \\
\mathbf{0 . 3}\end{array}$ & $\begin{array}{r}0 \\
0.13\end{array}$ & \\
\hline Ameiridae sp. 4 & 0 & 0 & 0 & 0 & 9 & 0 & 06 & 9.637 & 0 & 0 & 0 & 17 & $\begin{array}{r}35 \\
0.0\end{array}$ & 1 & \\
\hline Ameiridae sp. 5 & 0 & 0 & 0 & 0 & 0 & 0 & 0 & 0 & 0 & 0 & 0 & 0 & 88 & 0 & \\
\hline Family Ancorabolidae & & & & 0.0 & & & 0.0 & & 0.0 & & & & 0.0 & & \\
\hline Lobopleura expansa & 0 & 0 & 0 & 24 & 0 & 0 & 12 & 0.175 & 31 & 0 & 0 & 0 & 12 & 0 & \\
\hline Familiy Argestidae & & & & & & & & & & & & & 0.1 & & \\
\hline Argestidae sp. & 0 & 0 & 0 & 0 & 0 & 0 & 0 & 0 & 0 & 0 & 0 & 0 & $\begin{array}{r}53 \\
0.0\end{array}$ & 0 & \\
\hline Argestidae sp. 2 & 0 & 0 & 0 & 0 & 0 & 0 & 0 & 0 & 0 & 0 & 0 & 0 & $\begin{array}{r}47 \\
0.0\end{array}$ & 0 & \\
\hline $\begin{array}{l}\text { Argestidae sp. } 4 \\
\text { Familiy Cletodidae }\end{array}$ & 0 & 0 & 0 & 0 & 0 & 0 & 0 & 0 & 0 & 0 & 0 & 0 & 47 & 0 & \\
\hline Cletodidae sp. 1 & 0 & 0 & 0 & 0 & 0 & 0 & $\begin{array}{r}0.0 \\
06\end{array}$ & 0 & 0 & 0 & 0 & 0 & $\begin{array}{r}0 \\
0.0\end{array}$ & 0 & \\
\hline Cletodidae sp. 2 & 0 & 0 & 0 & 0 & 0 & 0 & 0 & 0 & 0 & 0 & $\begin{array}{r}0 \\
0.00\end{array}$ & 0 & 06 & 0 & \\
\hline $\begin{array}{l}\text { Cletodidae sp. } 3 \\
\text { Family } \\
\text { Ectinosomatidae }\end{array}$ & 0 & 0 & 0 & 0 & 0 & 0 & 0 & 0 & 0 & 0 & 4 & 0 & 0 & 0 & \\
\hline
\end{tabular}




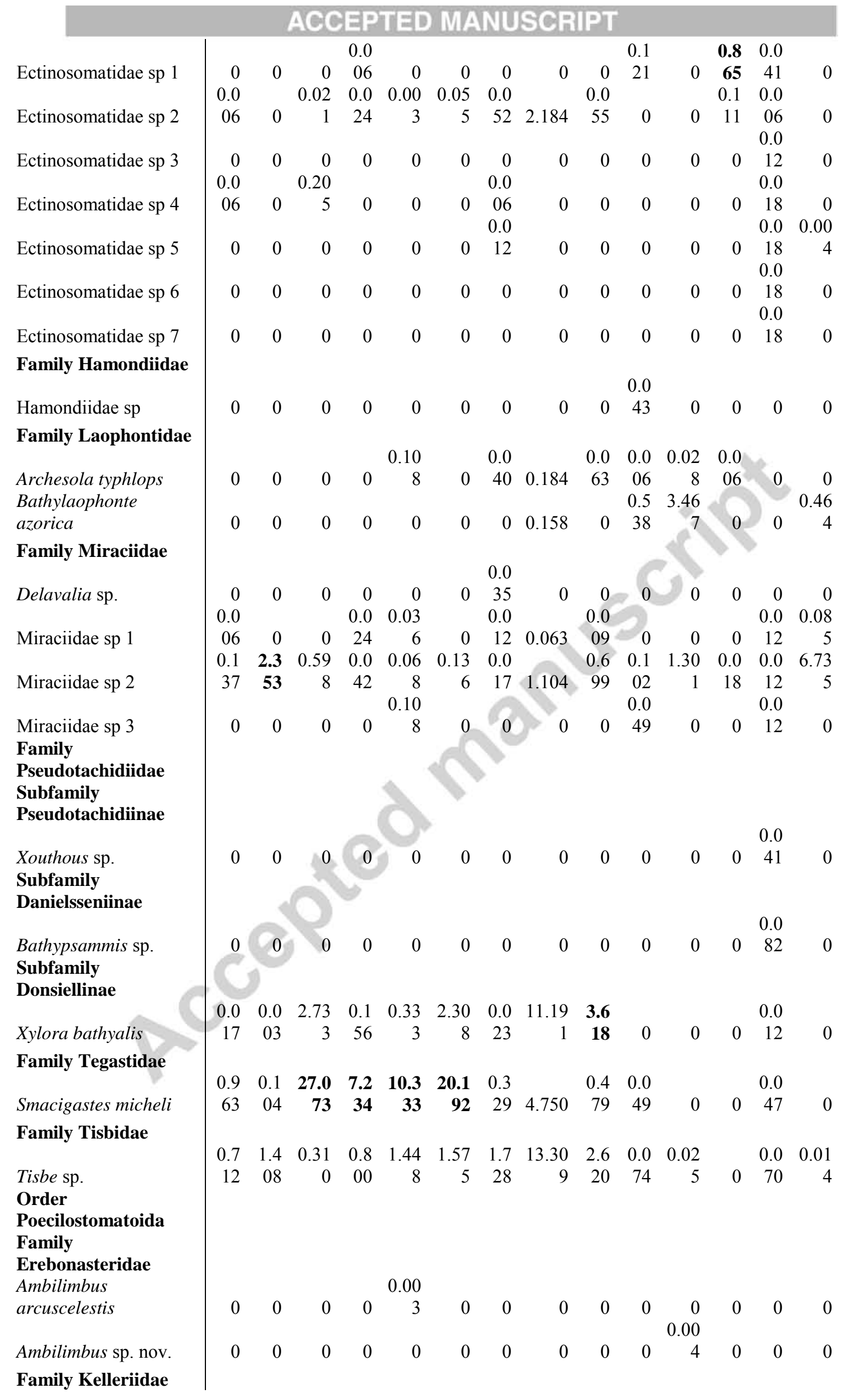




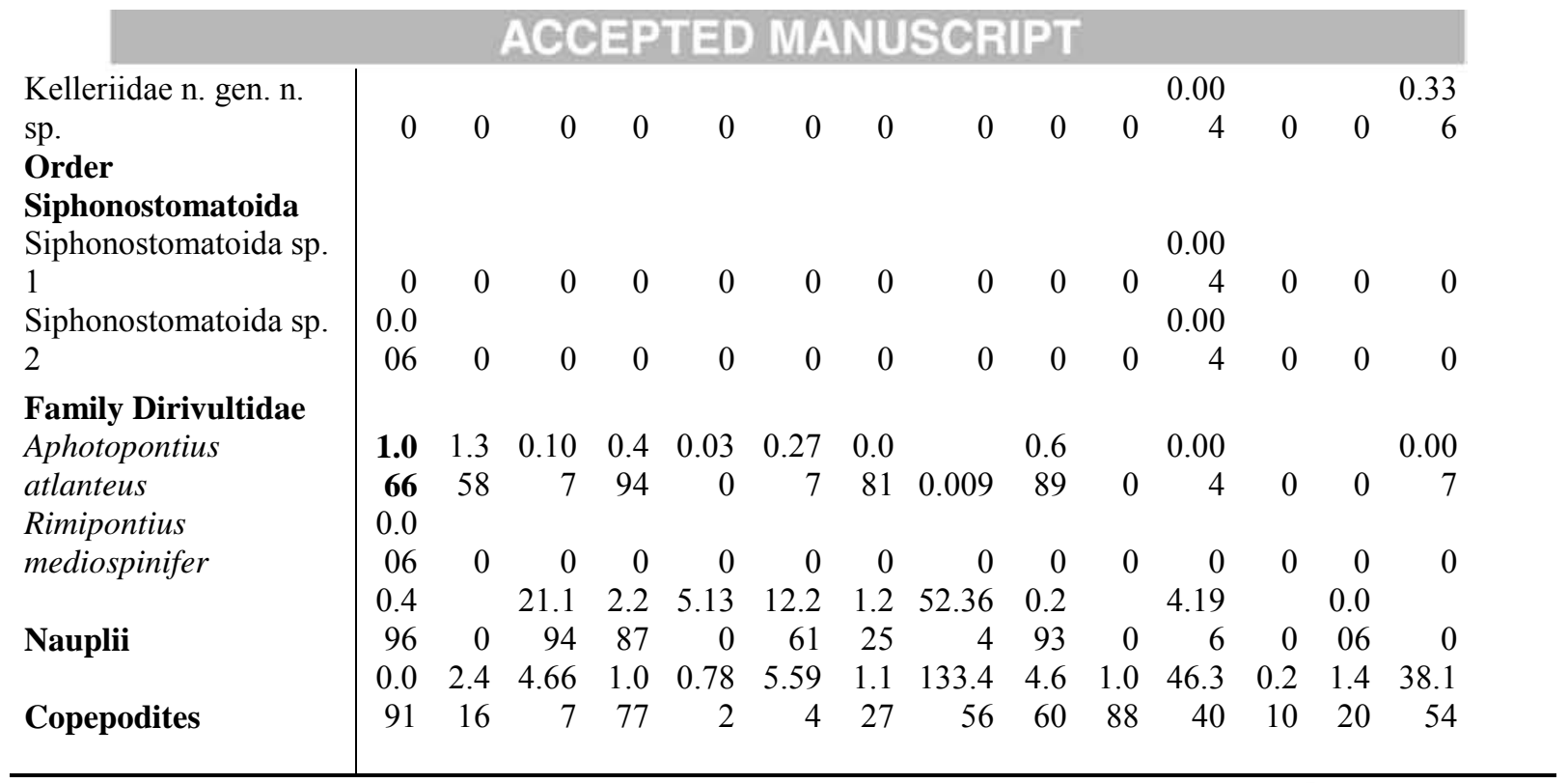

Figure 1: a) Location of the Lucky Strike vent field on the Mid-Atlantic-Ridge (MAR) at $37^{\circ} 117.59$ N, $32^{\circ} 11.69$ W. b) Lucky Strike with the location of the Eiffel Tower edifice south-east of the central lava lake including the positions of all deployment sites (1-5) along a gradient of hydrothermal activity (from 'high' to 'inactive'). c) Inset showing the location of sites 1-3 in the vicinity of the Eiffel Tower. At each site a stack of slate panels (A), a piece of wood (B), and a pig bone (C) were deployed. The slates were equipped with a NKE temperature probe.

Figure 2: Copepod density $(\ln )$ per $10 \mathrm{~cm}^{2}$ surface area of three substrata (slate, wood, bone) along a gradient of fluid input. Copepodites are included. N.a. = not available. For corresponding sites along the emission gradient see Table 2.

Figure 3: Copepod relative abundance ( $>5 \%,<5 \%$ pooled as others) per $10 \mathrm{~cm}^{2}$ surface area of the three substrata deployed along the gradient of fluid input. N.a. = not available.

Figure 4: Principal component analysis (PCoA) plot based on Bray-Curtis similarity of Hellinger-transformed copepod densities from three substrata deployed along five sites at the Eiffel Tower edifice. PCoA axis $1(37.5 \%)$ and $2(18.5 \%)$ explain $56 \%$ of the total variation in similarity between samples. Species vectors (blue lines) indicate the contribution of descriptors (species) to the similarity. Only species that contributed more than $5 \%$ to the 


\section{ACCEPTED MANUSCRIPT}

dis/similarity between groups in the SIMPER analyses are displayed. For abbreviations see Figure 1 and Table 2.

Figure 5: Canonical redundancy analysis (RDA, scaling type 1) of Hellinger-transformed copepod densities observed on three substrata distributed along five sites near the Tour Eiffel edifice, as a function of environmental factors (habitat, max. temp. ${ }^{\circ} \mathrm{C}$, fluid input). Axis RDA1 represents $26.03 \%$ of the total variance in copepod abundance while RDA2 represents only $7.48 \%$. Only indicator species, representing either the active (right-hand site) or inactive sites (left-hand site), are plotted. For abbreviations see Figure 1 and Table 2.

Figure 6: Simplified conceptual overview of copepod community patterns at the LS vent field in response to temperature and fluid input along a gradient of hydrothermal activity. The upper graph shows response in copepod density for different substrata along a gradient in fluid input. Illustrations below reflect the gradual change in community composition and copepod diversity along a gradient in temperature and fluid input from active to inactive areas. 


\section{ACCEPTED MANUSCRIPT}

Fig. 1

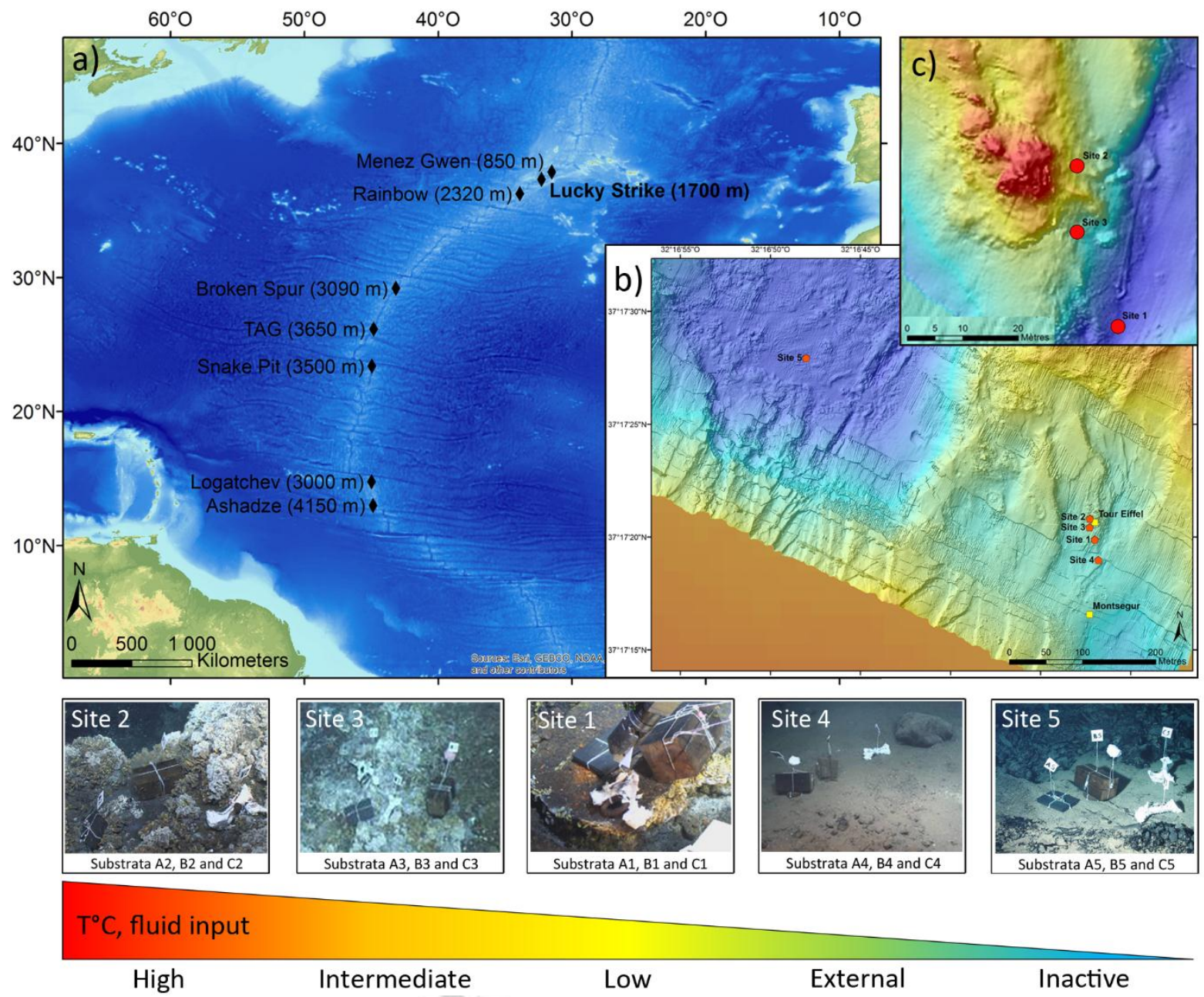


Fig. 2

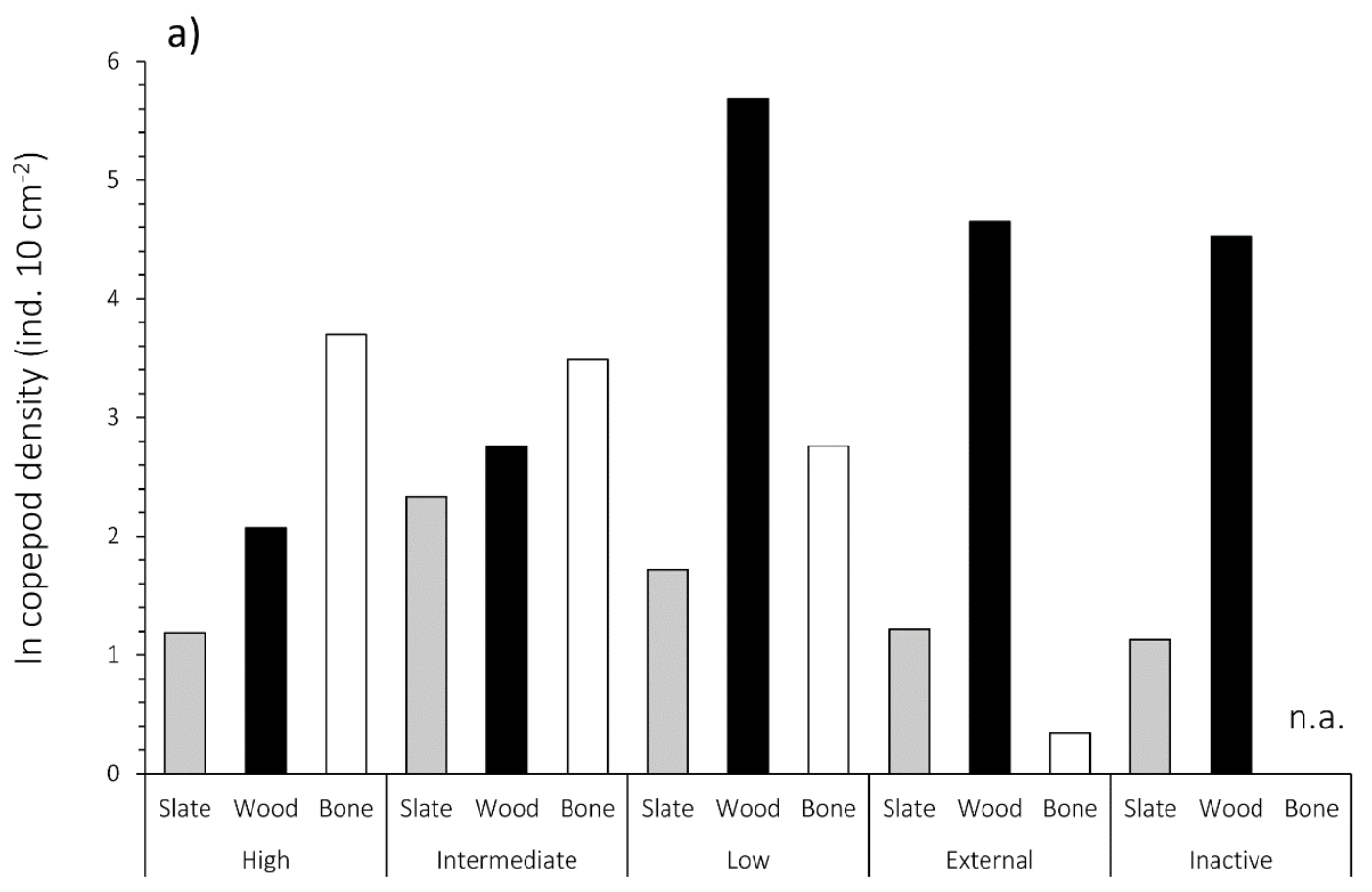

b)

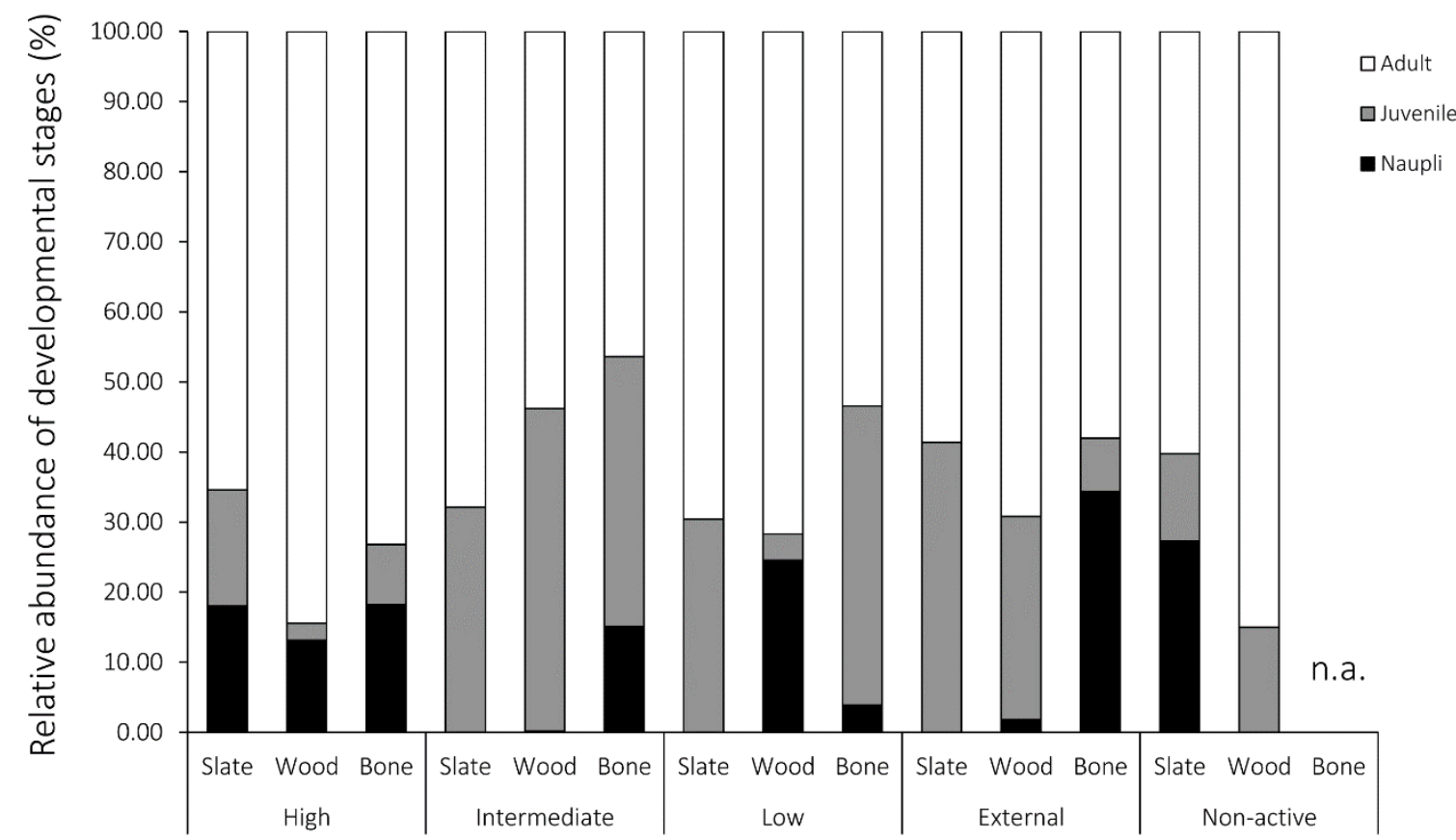


Fig. 3

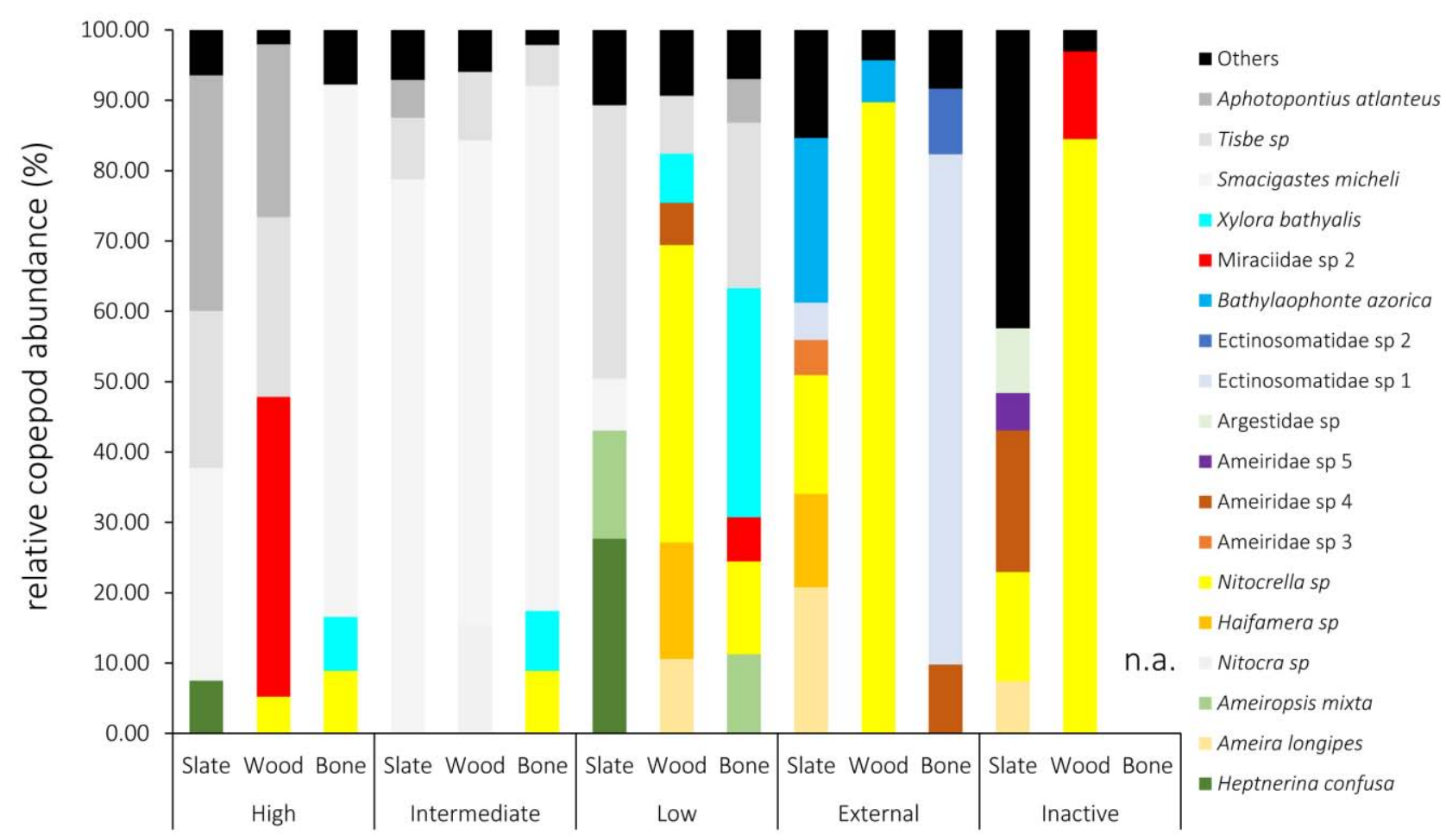

Fig. 4 


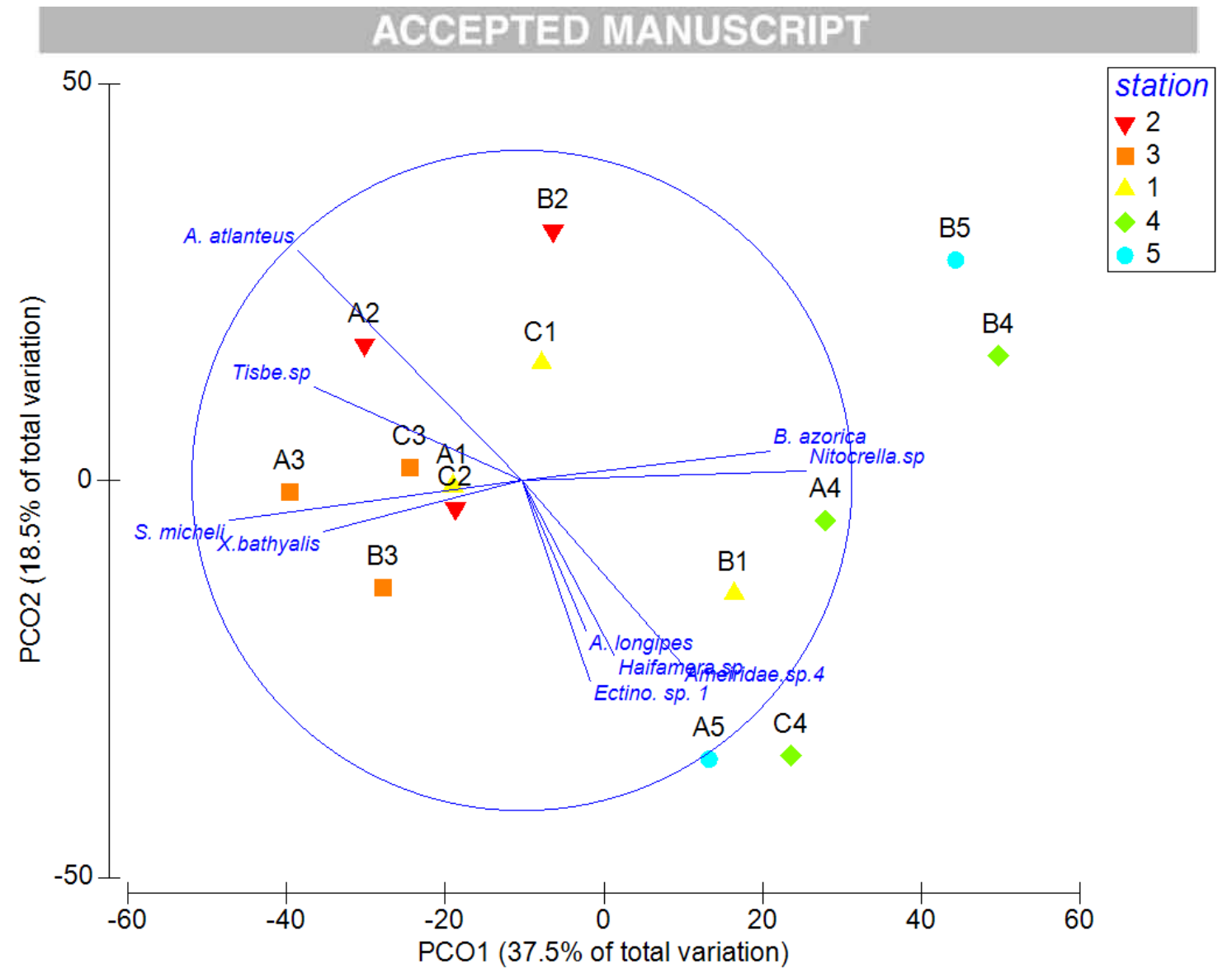




\section{ACCEPTED MANUSCRIPT}

Fig. 5

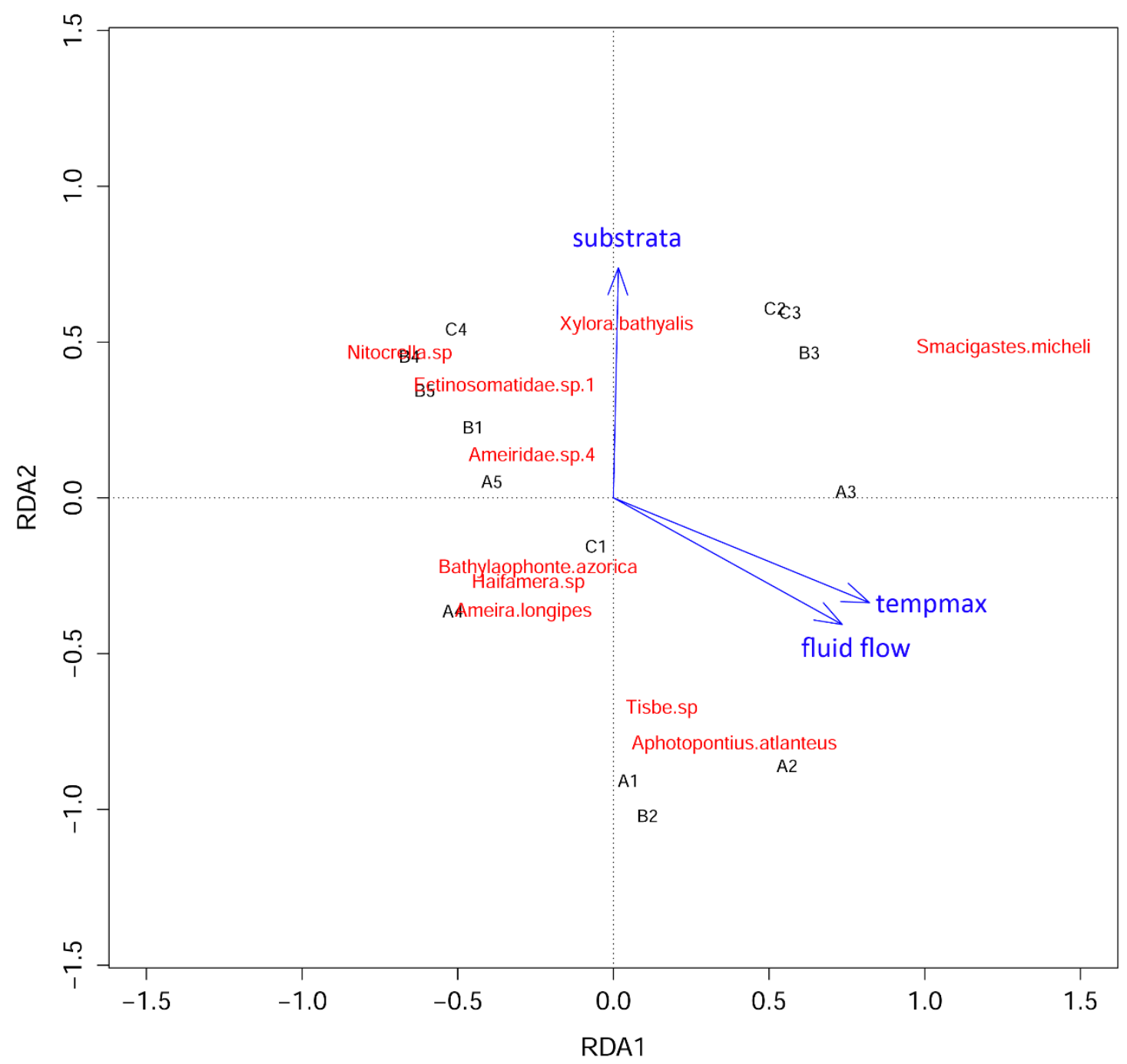




\section{ACCEPTED MANUSCRIPT}

Fig. 6

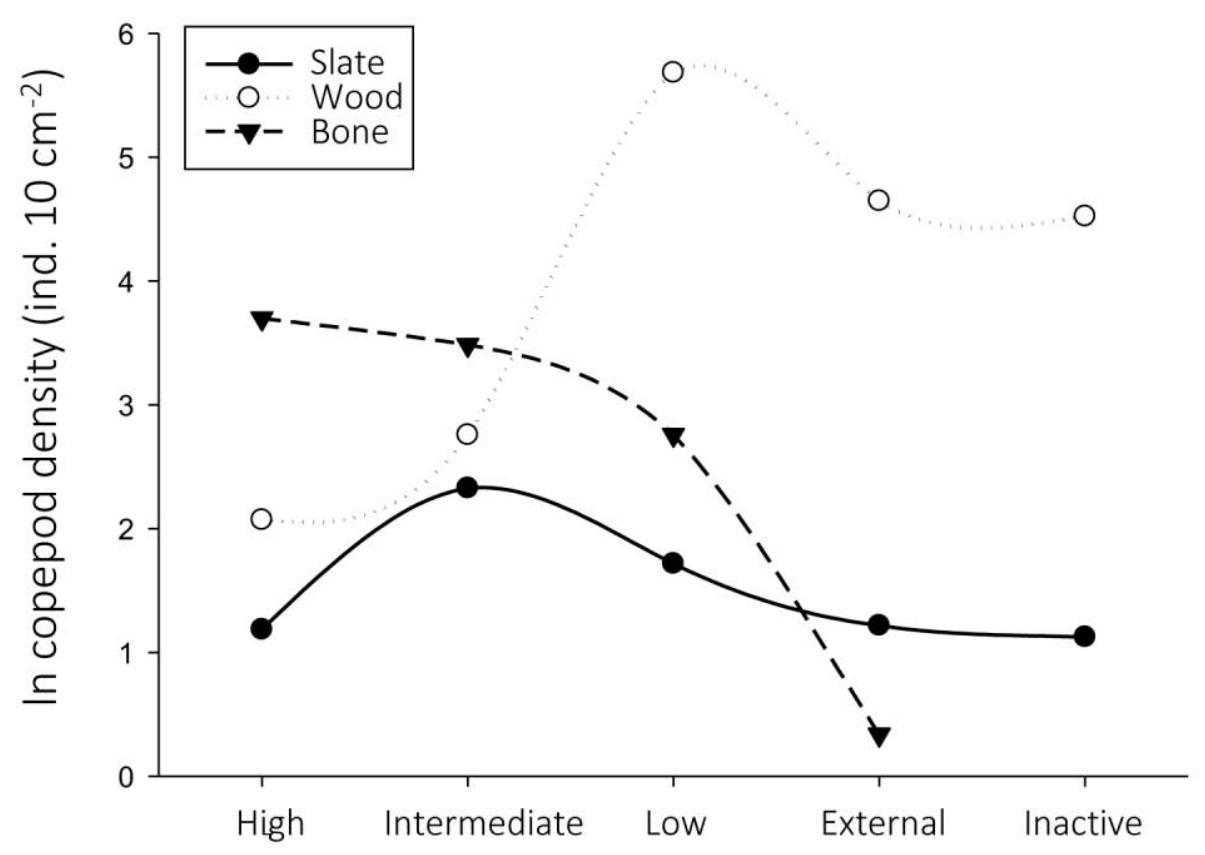

\begin{tabular}{|ccc|}
\hline & Community composition & \\
Specialists & Mixed & Non-vent species \\
\end{tabular}

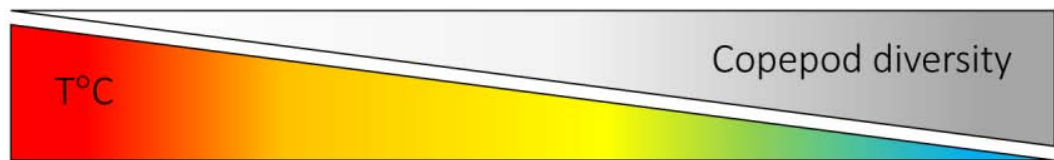

Active

Inactive 